\title{
Article \\ From the Physicochemical Characteristic of Novel Hesperetin Hydrazone to Its In Vitro Antimicrobial Aspects
}

\author{
Anna Sykuła 1,*(D), Elżbieta Łodyga-Chruścińska ${ }^{1}$, Eugenio Garribba ${ }^{2}$ (D), Dorota Kręgiel ${ }^{3}$ (D), \\ Aliaksandr Dzeikala ${ }^{1}$, Elżbieta Klewicka ${ }^{4}$ (D) and Lidia Piekarska-Radzik ${ }^{4}$
}

check for

updates

Citation: Sykuła, A.; Łodyga-

Chruścińska, E.; Garribba, E.; Kręgiel,

D.; Dzeikala, A.; Klewicka, E.;

Piekarska-Radzik, L. From the

Physicochemical Characteristic of

Novel Hesperetin Hydrazone to Its In

Vitro Antimicrobial Aspects.

Molecules 2022, 27, 845. https://

doi.org/10.3390/molecules27030845

Academic Editor: Ivan Kosalec

Received: 27 December 2021

Accepted: 25 January 2022

Published: 27 January 2022

Publisher's Note: MDPI stays neutral with regard to jurisdictional claims in published maps and institutional affiliations.

Copyright: (C) 2022 by the authors. Licensee MDPI, Basel, Switzerland. This article is an open access article distributed under the terms and conditions of the Creative Commons Attribution (CC BY) license (https:// creativecommons.org/licenses/by/ $4.0 /)$.
1 Institute of Natural Products and Cosmetics, Faculty of Biotechnology and Food Sciences, Lodz University of Technology, 90-537 Łódź, Poland; elzbieta.lodyga-chruscinska@p.lodz.pl (E.Ł.-C.); aliaksandr.dzeikala@gmail.com (A.D.)

2 Department of Medical, Surgical and Experimental Sciences, University of Sassari, Viale San Pietro, I-07100 Sassari, Italy; garribba@uniss.it

3 Department of Environmental Biotechnology, Faculty of Biotechnology and Food Sciences, Lodz University of Technology, 90-530 Łódź, Poland; dorota.kregiel@p.lodz.pl

4 Institute of Fermentation Technology and Microbiology, Faculty of Biotechnology and Food Sciences, Lodz University of Technology, 90-530 Łódź, Poland; elzbieta.klewicka@p.lodz.pl (E.K.); lidia.piekarska-radzik@edu.p.lodz.pl (L.P.-R.)

* Correspondence: anna.sykula@p.lodz.pl

\begin{abstract}
Microorganisms are able to give rise to biofilm formation on food matrixes and along food industry infrastructures or medical equipment. This growth may be reduced by the application of molecules preventing bacterial adhesion on these surfaces. A new Schiff base ligand, derivative of hesperetin, HABH (2-amino-N'-(2,3-dihydro-5,7-dihydroxy-2-(3-hydroxy-4-methoxyphenyl)chromen4-ylidene)benzohydrazide), and its copper complex, $\mathrm{CuHABH}\left[\mathrm{CuLH}_{2}(\mathrm{OAc})\right]$, were designed, synthesized and analyzed in terms of their structure and physicochemical properties, and tested as antibacterial agents. Their structures both in a solid state and in solution were established using several methods: FT-IR, ${ }^{1} \mathrm{H}$ NMR, ${ }^{13} \mathrm{C}$ NMR, UV-Vis, FAB MS, EPR, ESI-MS and potentiometry. Coordination binding of the copper(II) complex dominating at the physiological $\mathrm{pH}$ region in the solution was found to be the same as that detected in the solid state. Furthermore, the interaction between the $\mathrm{HABH}$ and $\mathrm{CuHABH}$ with calf-thymus DNA (CT-DNA) were investigated. These interactions were tracked by UV-Vis, CD (circular dichroism) and spectrofluorimetry. The results indicate a stronger interaction of the $\mathrm{CuHABH}$ with the CT-DNA than the HABH. It can be assumed that the nature of the interactions is of the intercalating type, but in the high concentration range, the complex can bind to the DNA externally to phosphate residues or to a minor/major groove. The prepared compounds possess antibacterial and antibiofilm activities against Gram-positive and Gram-negative bacteria. Their antagonistic activity depends on the factor-strain test system. The glass was selected as a model surface for the experiments on antibiofilm activity. The adhesion of bacterial cells to the glass surface in the presence of the compounds was traced by luminometry and the best antiadhesive action against both bacterial strains was detected for the CuHABH complex. This molecule may play a crucial role in disrupting exopolymers (DNA/proteins) in biofilm formation and can be used to prevent bacterial adhesion especially on glass equipment.
\end{abstract}

Keywords: antibiofilm molecules; Schiff bases; copper complexes; antibacterial activities; antiadhesive action

\section{Introduction}

Diverse microorganisms are able to grow on food matrixes and along food industry infrastructures and this growth may give rise to biofilms [1]. Knowledge of the bacterial species responsible for the pre-colonization, maturation and dispersal of biofilms in the food industry is very important due to the health problems associated with, for example, dairy 
products, ready-to-eat foods or alimentary goods [1]. These human pathogens include, but are not limited to, Escherichia coli (which may include enterotoxic and even hemorrhagic strains), Listeria monocytogenes (a species ubiquitous in soil and water that can lead to abortion in pregnant women and other serious complications in children and the elderly), and Staphylococcus aureus (known to have numerous intestinal toxins) [1-3].

The pathogens are able to develop biofilm structures on different artificial substrates common in the food industry, such as glass, stainless steel, polyethylene, wood, polypropylene, rubber, etc. Biofilm formation represents a special mode of growth that renders microbial cells more resistant to antimicrobials enabling the pathogens to survive in hostile environments and also to disperse and colonize new niches. Numerous studies have analyzed the possible relationship between biofilm formation and antimicrobial resistance [4-6].

Microbial resistance is multifactorial; there are multiple mechanisms of resistance that act together in order to provide an increased overall level of resistance to the biofilm. These mechanisms are based on the function of wild-type genes and are not the result of mutations [7].

Bacterial species that make up the biofilms show genomic differences with respect to key genes involved in biofilm characterization, leading to the formation of completely different biofilms under different conditions [8]. This complexity, together with the great variety of environments affected and the diversity of bacterial colonizing species, complicates biofilm removal in the food industry.

The global spread of antibiotic resistance among important human pathogens emphasizes the need to find new antibacterial drugs with a novel mode of action. These new antibiofilm agents, which contain moieties such as phenols, imidazole, sulfide, furanone, etc., have the potential to disperse bacterial biofilms in vivo and could positively impact human medicine in the future. Nature continues to inspire the discovery of new compounds with interesting structures and biological activities and these naturally-derived compounds have served as scaffolds for the development of many synthetic therapeutic agents. This has prompted us to investigate derivatives of natural flavonoids.

Flavonoids are considered as natural therapeutics playing major roles in successful medical treatments in ancient as well as modern times [9]. They belong to the group of compounds inhibiting biofilm formation [10]. We have undertaken research on hesperetin, one of the representatives of flavonoids belonging to the flavanone subgroup. On the one hand, Schiff's bases are well known as active compounds and exhibit a range of activities, including antimicrobial activity [11-13]. Moreover, the Schiff bases' metal complexes have been of major interest for a long time because of their more significant antimicrobial potency [14-16]. This inspired us to take up the challenge of synthesizing the Schiff bases of flavanone and we have documented that hesperetin or naringenin bonded to the azomethine group associated with active benzohydrazide or thiosemicarbazide moieties that showed a DNA damaging potency and antibacterial activity $[17,18]$.

In the present work we have focused on the research of a novel compound $(\mathrm{HABH})$ synthesized by the condensation of 2-aminobenzhydrazide and hesperetin (Figure 1) and its copper(II) complex $(\mathrm{CuHABH})$. Their structure and physicochemical properties were characterized by spectroscopic (FT-IR, ${ }^{1} \mathrm{H}$ NMR, ${ }^{13} \mathrm{C}$ NMR, UV-Vis, FAB MS, EPR, ESI-MS) and electrochemical techniques. These compounds were screened for in vitro antibacterial activity against seven different bacterial strains and for antibiofilm activities against Grampositive Staphylococcus aureus and Gram-negative Escherichia coli strains. 


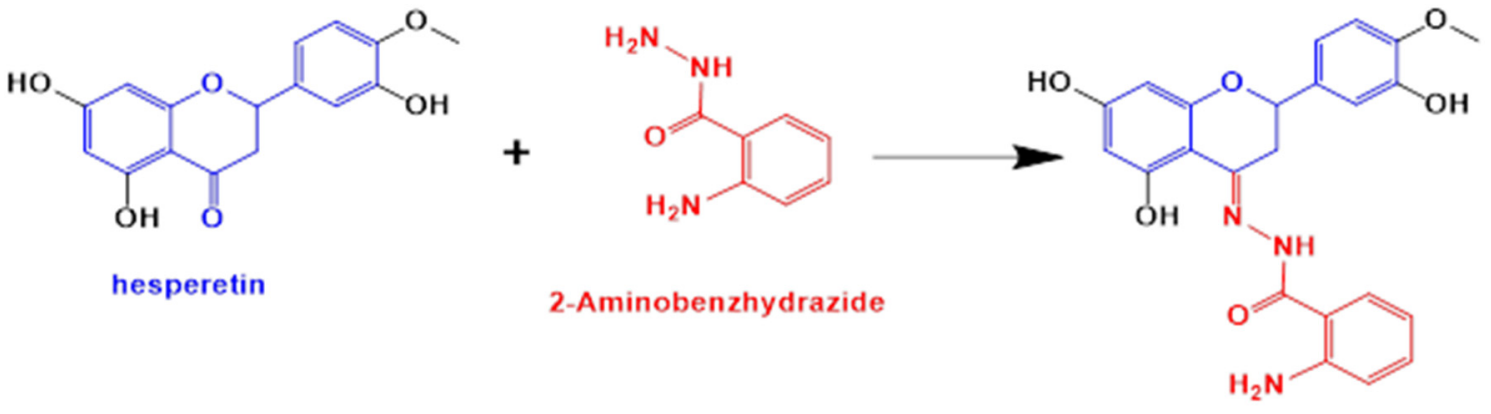

Figure 1. Synthesis of 2-amino-N'-(2,3-dihydro-5,7-dihydroxy-2-(3-hydroxy-4-methoxyphenyl)chromen4-ylidene)benzohydrazide (HABH).

Adhesion to the surfaces of inert materials, such as glass or plastics, has been recognized as resulting from physicochemical interactions between different components (microorganism, substrate and suspending medium). Under the biofilm state, bacteria produce the extracellular polymeric substances in order to build up the matrix that holds the sessile cells together. Recently, extracellular exopolysaccharides, extracellular DNA and proteins [19-21] have been found as the main components of the biofilm matrix. With this in mind, we have made an attempt to establish the interactions of $\mathrm{HABH}$ and $\mathrm{CuHABH}$ with CT DNA, the molecule used in model studies of the interaction of compounds with potential biological activity. These interactions have been tracked by spectrofluorimetry. Adhesion of the bacterial cells to the glass surface in the presence of the compounds were traced by luminometry.

\section{Materials and Methods}

\subsection{Materials in the Synthesis of Novel Hesperetin Derivatives}

The racemic hesperetin, 2-aminobezhydrazide, and all other compounds were purchased from Sigma-Aldrich Co. (Poznań, Poland). All reagents were of an analytical quality and were used without further purification.

\subsection{Apparatus}

The structure of the compounds obtained was determined by: elemental analysis (C, H, N) on the EuroVector 3018 analyzer (EuroVector, Milan, Italy); analysis of the FABMS mass spectra made on a Finnigan MAT 95 mass spectrometer (Finnigan MAT, San Jose, CA, USA); and analysis of the IR spectra using an FT-IR spectrometer Nicolet 6700 (Thermo Scientific, Waltham, MA, USA) in the range of $4000-350 \mathrm{~cm}^{-1}$. The melting point of the ligands was determined on an Electrothermal 9200 microscopic melting point apparatus (Cole-Parmer Ltd., Stone, Staffordshire, UK). ${ }^{1} \mathrm{H}$ NMR spectra analyses were also performed on a Bruker Avance III WB 400-MHz spectrometer (Bruker, Ettlingen, Germany) in DMSO- $\mathrm{d}_{6}$ with tetramethylsilane (TMS) as an internal standard. Chemical shifts were expressed in parts per million (ppm, $\delta$ ) and were referenced to DMSO- $\mathrm{d}_{6}(\delta=2.50 \mathrm{ppm})$ as an internal standard. The ${ }^{13} \mathrm{C}$ NMR spectra were also obtained using a Bruker Avance III 400 spectrometer (Bruker, Ettlingen, Germany) that operated at $100 \mathrm{MHz}$. Chemical shifts were expressed in parts per million (ppm, $\delta)$ and were referenced to DMSO- $\mathrm{d}_{6}(\delta=39.52 \mathrm{ppm})$ as an internal standard. All NMR spectra were taken in DMSO-d ${ }_{6}$ (Deutero Gmbh, Kastellaun, Denmark). UV-Vis spectra of the compounds in the DMSO and in the mixture of $70 \%$ $\mathrm{HCl}(\mathrm{NaCl}) / 30 \%$ were recorded in the $\lambda$ interval 200-900 nm using a Hewlett-Packard 8453 spectrophotometer running 845x UV-Visible ChemStation Software (Agilent, Mulgrave, Victoria, Australia). Solutions were inserted in a quartz cell with a path length of $1 \mathrm{~cm}$. The content of copper in the complex was determined by a 932 AA spectrophotometer from GBC (Dandenong, VIC, Australia) with a deuterium background correction used. The system was controlled by a data station running the GBC Avanta Version 1.33 (GBC, 932 AA spectrophotometer, Dandenong, VIC, Australia). 
The formation of the new compounds was monitored by electrospray ionization mass spectrometry (ESI-MS, Bruker Daltonics GmbH, Bremen, Germany) analysis in the negative ion mode. Before the analysis, the samples were dissolved in acetonitrile $(250 \mu \mathrm{g} / \mathrm{mL})$ and injected directly into a Q-Exactive Orbitrap ${ }^{\mathrm{TM}}$ (Thermo Scientific, Bellefonte, PA, USA) tandem mass spectrometer equipped with a heated electrospray ionization (ESI) interface (HESI-II), using an injection pump and a $500 \mu \mathrm{L}$ syringe (Thermo Scientific, Bellefonte, PA, USA). The injection speed was $10 \mu \mathrm{L} / \mathrm{min}$. The new compounds were analyzed using fullscan MS and a subsequent parallel reaction monitoring (PRM, Thermo Scientific, Hudson, $\mathrm{NH}, \mathrm{USA}$ ) mode with a scan range from 50 to $1000 \mathrm{~m} / \mathrm{z}$. The capillary temperature was adjusted to $320^{\circ} \mathrm{C}$. The electrospray capillary voltage and S-lens radio frequency (RF) level were set at $4.5 \mathrm{kV}$ and $50 \mathrm{~V}$, respectively. Nitrogen was used as both a sheath gas and auxiliary gas at a flow of 10 and 8 (arbitrary units), respectively. Ions that were selected by the quadrupole entered the higher energy collision dissociation (HCD) cell. An isolation window of 2 amu was used and the precursors were fragmented by a collision-induced dissociation C-trap (CID) with a normalized collision energy (NCE) of $25 \mathrm{~V}$. The ESI-MS/MS scan spectra (Bruker Daltonics GmbH, Bremen, Germany) were acquired with the mass resolution of 35,000 full-width at half-maximum (FWHM) at $m / z=100$. The automatic gain control (AGC) target (the number of ions to fill C-Trap) was set at $2.0 \times 10^{5}$ with a maximum injection time (IT) of $100 \mathrm{~ms}$. The instrument control, data acquisition, and evaluation were completed with the Q Exactive Tune 2.1 and Thermo Xcalibur 2.2 software (Thermo Fisher Scientific, Bremen, Germany).

\subsubsection{Characterization of $\mathrm{HABH}$}

HABH synthesis is presented in Figure 1.

The ligand 2-amino-benzoic acid [5,7-dihydroxy-2-(3-hydroxy-4-methoxy-phenyl)chroman-4-ylidene]-hydrazide $(\mathrm{HABH})$ was prepared according to the literature procedure $[22,23]$ with some modifications. The synthesis product was filtered off, washed with ethanol and methanol and then dried to give a solid ligand. The synthesis yield was $67 \%$.

The 2-amino-benzoic acid [5,7-dihydroxy-2-(3-hydroxy-4-methoxy-phenyl)-chroman4-ylidene]-hydrazide (HABH) was characterized by using several spectroscopic methods. Yield: $891 \mathrm{mg}$, 67\%; m.p. 264-266.5 ${ }^{0} \mathrm{C}$; ${ }^{1} \mathrm{H}$ NMR (DMSO-d $\left.6,400 \mathrm{MHz}\right) \delta: 2.92$ (dd, $\left.J_{1}=12.1 \mathrm{~Hz}, J_{2}=17.1 \mathrm{~Hz}, 1 \mathrm{H}\right), 3.39\left(\mathrm{dd}, J_{1}=3.0 \mathrm{~Hz}, J_{2}=17.2 \mathrm{~Hz}, 1 \mathrm{H}\right), 3.35(\mathrm{~s}, 3 \mathrm{H}), 5.09$ $\left(\mathrm{dd}, J_{1}=2.9 \mathrm{~Hz}, J_{2}=12.3 \mathrm{~Hz}, 1 \mathrm{H}\right), 5.87(\mathrm{~d}, J=2.2 \mathrm{~Hz}, 1 \mathrm{H}), 5.93(\mathrm{~d}, J=2.3 \mathrm{~Hz}, 1 \mathrm{H}), 6.33(\mathrm{bs}$, $1 \mathrm{H}), 6.53\left(\mathrm{td}, J_{1}=0.9 \mathrm{~Hz}, J_{2}=7.8 \mathrm{~Hz}, 1 \mathrm{H}\right), 6.74(\mathrm{~d}, J=7.8 \mathrm{~Hz}, 1 \mathrm{H}), 6.87-6.96(\mathrm{~m}, 3 \mathrm{H}), 7.10$ $\left(\mathrm{td}, J_{1}=1.4 \mathrm{~Hz}, J_{2}=8.1 \mathrm{~Hz}, 1 \mathrm{H}\right), 7.53(\mathrm{~d}, J=6.5 \mathrm{~Hz}, 1 \mathrm{H}), 9.11(\mathrm{~s}, 1 \mathrm{H}), 9.97(\mathrm{~s}, 1 \mathrm{H}), 10.80(\mathrm{bs}$, $1 \mathrm{H})$, and $13.16(\mathrm{~s}, 1 \mathrm{H}) ;{ }^{13} \mathrm{C}$ NMR $\left(\mathrm{DMSO}_{6}, \mathrm{~d}_{6}, 100 \mathrm{MHz}\right) \delta: 32.1,55.7,75.9,94.9,96.7,98.4$, $112.0,113.4,113.9,114.6,116.2,117.5,129.1,132.1,132.4,146.5,147.7,149.8,153.5,158.9$, 160.8 , and $161.3\left({ }^{1} \mathrm{H}\right.$ NMR and ${ }^{13} \mathrm{C}$ spectra of $\mathrm{HABH}$ are available as Figures S1 and S2 in Supplementary Materials); IR $\nu_{\max }\left(\mathrm{cm}^{-1}\right): v(\mathrm{O}-\mathrm{H}): 3421, v(\mathrm{~N}-\mathrm{H}): 3333, v(\mathrm{C}=\mathrm{O}): 1630$, $v(\mathrm{C}=\mathrm{N}): 1609, v(\mathrm{C}=\mathrm{C}): 1530, v(\mathrm{C}-\mathrm{O}): 1253, v(\mathrm{C}-\mathrm{O}-\mathrm{C}): 1150, v(\mathrm{C}-\mathrm{N}): 1017$, and $v(\mathrm{~N}-\mathrm{N}): 1020$; UV-Vis $\lambda_{\max }(\mathrm{nm}): 323,349 \mathrm{~nm}$; FAB-MS: $m / z=436[\mathrm{M}+\mathrm{H}]^{+}$; Anal. Calc. for $\mathrm{C}_{23} \mathrm{H}_{21} \mathrm{~N}_{3} \mathrm{O}_{6}$ : C, 63.44; H, 4.86; N, 9.65. Found: C, 63.39; H, 4.89; and N, 9.59.

\subsubsection{Characterization of Copper(II) Complex with HABH in Solid State}

An amount of $72.58 \mathrm{mg}(0.1169 \mathrm{mmol})$ of hesperetin 2-aminobenzoylhydrazone $(\mathrm{HABH})$ was quantitatively transferred to a round bottom flask and dissolved in $15 \mathrm{~mL}$ of acetone at $60{ }^{\circ} \mathrm{C}$. The contents of the flask were stirred for $10 \mathrm{~min}$ until the HABH was completely dissolved, then $35.60 \mathrm{mg}(0.1783 \mathrm{mmol})$ of $\mathrm{Cu}(\mathrm{OAc})_{2} \cdot \mathrm{xH}_{2} \mathrm{O}$ was added to the obtained solution, with one drop of triethylamine added as a catalyst and the reaction was carried out at $60^{\circ} \mathrm{C}$ within $5 \mathrm{~h}$. After this time, a dark green copper complex precipitated, which was suction filtered, washed with acetone and methanol and left to dry in the desiccator. The synthesis yield was $67 \%$.

For the $\left[\mathrm{CuLH}_{2}(\mathrm{OAc})\right]$ (CuHABH as abbreviation); Yield: $58.57 \mathrm{mg}, 63 \%$; Anal. Calc. $\mathrm{C}_{25} \mathrm{H}_{23} \mathrm{CuN}_{3} \mathrm{O}_{8}$ : C, 53.91; H, 4.16; N, 7.54; Cu, 11.41. Found: C, 53.63; H, 4.09; N, 7.48; 
$\mathrm{Cu}, 11.04 \%$. IR $v_{\max }\left(\mathrm{cm}^{-1}\right): v(\mathrm{~N}-\mathrm{H}): 3395, v(\mathrm{C}=\mathrm{O}): 1613, v(\mathrm{C}=\mathrm{N}): 1593, v_{a s}\left(\mathrm{COO}^{-}\right): 1563$, $v(\mathrm{C}=\mathrm{C}): 1436, v_{\mathcal{S}}\left(\mathrm{COO}^{-}\right): 1363, v(\mathrm{C}-\mathrm{O}): 1278 v(\mathrm{C}-\mathrm{O}-\mathrm{C}): 1159, v(\mathrm{C}-\mathrm{N}): 1068, v(\mathrm{~N}-\mathrm{N}): 1031$, $v(\mathrm{M}-\mathrm{O}): 445, v(\mathrm{M}-\mathrm{N}): 410$. UV-Vis $\lambda_{\max }(\mathrm{nm}): 284,338$ for $70 \% \mathrm{HCl}(\mathrm{NaCl}) / 30 \% \mathrm{DMSO}$ and 335; 289; 406 for 100\% DMSO. ESI-MS: $m / z=555.38$ [CuLH $\mathrm{CHAc}_{2}$ (OA[M-H] ${ }^{-}$(Mass spectrum is available as Figure S3).

\subsubsection{Stoichiometry Determination of the Copper(II) Complex with HABH in Solution Potentiometry}

Complex stoichiometry was determined by $\mathrm{pH}$-potentiometric titrations of $2.0 \mathrm{~mL}$ samples in DMSO/water mixtures (30\%:70\% v/v) due to the slight solubility of the $\mathrm{CuHABH}$ in pure water (Figure S4A) and the UV-Vis (Figure S6) and EPR studies. The ligand:metal molar ratio was $1: 1$, the concentrations of $\mathrm{Cu}(\mathrm{II})$ and the ligand were $1 \times 10^{-3} \mathrm{M}$. The measurements were carried out at $298 \mathrm{~K}$ and at a constant ionic strength of $0.1 \mathrm{M} \mathrm{KCl}$ with a MOLSPIN pH meter (Molspin Ltd., Newcastle-upon-Tyne, UK), equipped with a digitally operated syringe (the Molspin DSI $0.250 \mathrm{~mL}$ ) controlled by computer. The titrations were performed with a carbonate-free $\mathrm{NaOH}$ solution of a known concentration (ca. 0.1 M) using a Russel CMAWL/S7 semi-micro combined electrode. The $\mathrm{pH}$ measuring circuit was calibrated with potassium hydrogen phthalate and phosphate buffers. The number of experimental points was 100-150 for each titration curve. The reproducibility of the titration points included in the evaluation was within $0.005 \mathrm{pH}$ units in the whole $\mathrm{pH}$ range examined (2.0-11.5). Complex stoichiometry and diagram distributions of the protonated/deprotonated species were revealed (Figures S4B,C and S5) using the computer program SUPERQUAD [24]. The procedure of the calculations was adopted from our previous works $[17,18]$.

\section{Spectroscopy and Computational Details}

The presence of protonated/deprotonated species was supported by electronic absorption (UV-Vis) spectra recorded in the DMSO/water mixture $(30 \% / 70 \% \mathrm{v} / \mathrm{v}$ fraction) at a different $\mathrm{pH}$ corresponding to the dominant species of the $\mathrm{HABH}$ or $\mathrm{CuHABH}$. $\mathrm{C}_{\mathrm{HABH}}=\mathrm{C}_{\mathrm{CuHABH}}=1 \times 10^{-5} \mathrm{M}$. Spectra were recorded with a Perkin-Elmer Lambda 11 spectrophotometer (Perkin Elmer, Ueberlingen, Germany) using a quartz cell with a path length of $1 \mathrm{~cm}$ (Figure S6). Coordination modes of the copper complexes with the HABH were studied by electron paramagnetic resonance (EPR) spectroscopy. The spectra were recorded from 0 to 8000 Gauss at room temperature $(298 \mathrm{~K})$ or liquid nitrogen temperature (77 K) with an X-band Bruker EMX spectrometer (Bruker Corporation, Billerica, MA, USA) equipped with a HP 53150A microwave frequency counter. The spectra in an aqueous solution as a function of the $\mathrm{pH}$ were recorded on the system ${ }^{63} \mathrm{CuSO}_{4} \cdot 5 \mathrm{H}_{2} \mathrm{O} / \mathrm{H}_{4} \mathrm{ABH} 1: 1$ with a $\mathrm{Cu}$ II concentration of $1.0 \times 10^{-3} \mathrm{M}$. The ${ }^{63} \mathrm{CuSO}_{4} \cdot 5 \mathrm{H}_{2} \mathrm{O}$, used for a better resolution of the EPR spectra, was prepared from metallic copper $\left(99.3 \%{ }^{63} \mathrm{Cu}\right.$ and $\left.0.7 \%{ }^{65} \mathrm{Cu}\right)$ purchased from JV Isoflex (Isoflex, Moscow, Russian Federation). The microwave frequency used to record the spectra was in the range 9.40-9.42 GHz, microwave power was $20 \mathrm{~mW}$, the time constant was $163.8 \mathrm{~ms}$, modulation frequency $100 \mathrm{kHz}$, modulation amplitude 4 Gauss, sweep time 335.5 s, and the resolution 2048 (range 2500-3500 Gauss) or 8192 (range 0-8000 Gauss) points. To extract the experimental spin Hamiltonian parameters, WinEPR SimFonia (Bruker Analytische Messtechnik GmbH, Karlshrue, Germany) software was used [25]. The geometry was optimized, and harmonic frequencies were computed with Gaussian 09 software [26] at the DFT theory level. The hybrid Becke three-parameter B3LYP functional $[27,28]$, coupled with the Grimme's D3 dispersion was used combined with the split-valence Pople basis set $6-311 \mathrm{~g}(\mathrm{~d}, \mathrm{p})$ for the main group elements, while the Stuttgard-Dresden (SDD) implemented with $f$-functions and pseudo-potential was applied for the $\mathrm{Cu}$. These conditions have been successfully applied and discussed in the literature for the geometry prediction of first-row transition metal complexes [29-31]. The $g$ and $A$ tensors of the ${ }^{63} \mathrm{Cu}$ center were calculated with the ORCA program [32-34], using the 
functionals PBE0 $[35,36]$ and B3LYP $[27,28]$, respectively, as recently established in the literature [37].

\subsection{DNA Studies}

\subsubsection{Electronic Absorption Titration}

Electronic absorption spectra of the compounds HABH, CuHABH and HESP $(25 \mu \mathrm{M})$ were recorded with a gradual increasing concentration of CT-DNA $(0-63 \mu \mathrm{M})$. The intrinsic binding constant $\left(K_{b}\right)$ of the complex with the CT-DNA was determined using the following equation [38] (Equation (1)):

$$
[D N A] /\left(\varepsilon_{a}-\varepsilon_{f}\right)=[D N A] /\left(\varepsilon_{b}-\varepsilon_{f}\right)+1 /\left[K_{b}\left(\varepsilon_{b}-\varepsilon_{f}\right)\right]
$$

where [DNA] is the concentration of CT-DNA, $\varepsilon_{a}$ is the molar extinction coefficient of the compound at a given CT-DNA concentration, and $\varepsilon_{f}$ and $\varepsilon_{b}$ are the extinction coefficients of the compound in free solution and when fully bound to the CT-DNA, respectively. The plot of $[D N A] /\left(\varepsilon_{a}-\varepsilon_{f}\right)$ vs. [DNA] gives a straight line with $1 /\left(\varepsilon_{b}-\varepsilon_{f}\right)$ and $1 /\left[K_{b}\left(\varepsilon_{b}-\varepsilon_{f}\right)\right]$ as the slope and intercept, respectively. From the ratio of the slope to the intercept, the value of $K_{b}$ was calculated.

\subsubsection{Competitive Binding Fluorescence Measurement}

The thiazole orange (TO)-competitive studies of each compound were carried out with fluorescence spectroscopy to examine whether the compounds tested can replace TO in the TO bounded CT-DNA system. An aqueous solution of TO $(25 \mu \mathrm{M})$ bounded to the CT-DNA $(25 \mu \mathrm{M})$ was prepared in a Tris- $\mathrm{HCl}(\mathrm{NaCl})$ buffer $(\mathrm{pH} 7.2)$ and this was titrated with solutions of the tested compounds (concentrations in the range of 10-300 $\mu \mathrm{M}$ ). In the presence of CT-DNA, thiazole orange (TO) exhibits a fluorescence $\left(\lambda_{\mathrm{em}}=527 \mathrm{~nm}\right.$, $\lambda_{\text {ex }}=509 \mathrm{~nm}$ ) [39] enhancement due to its intercalative binding to DNA. Competitive binding of compounds with the CT-DNA results in fluorescence quenching due to the displacement of TO from CT-DNA. The Stern-Volmer constant $\left(K_{S V}\right)$ was calculated using the Stern-Volmer equation [40,41] (Equation (2)):

$$
I_{0} / I=1+K_{S V}[Q]
$$

where $I_{0} / I$ is the fluorescence quenching index, $I_{0}$ and $I$ are the fluorescence emission intensities in the absence and presence of the quencher (tested compound), respectively, $K_{S V}$ is the Stern-Volmer constant and $[Q]$ is the concentration of the quencher. Taking $\tau_{o}=2.6 \mathrm{~ns}$ as the fluorescence lifetime of the TO-DNA adduct [42], the quenching constants $\left(k_{q}\right.$, in $\mathrm{M}^{-1} \mathrm{~s}^{-1}$ ) of the compounds were calculated according to Equation (3) [40]:

$$
K_{S V}=k_{q} \tau_{o}
$$

\subsubsection{Circular Dichroism Spectroscopy Analysis}

Circular dichroism (CD) spectra of the CT DNA with the HABH and CuHABH were recorded using the Jasco J815 CD spectropolarimeter (Jasco, Easton, MD, USA) in the wavelength range $(\lambda) 200-460 \mathrm{~nm}$ at room temperature ( $298 \mathrm{~K})$ using quartz cuvettes with a $0.5 \mathrm{~cm}$ optical path, applied bandwidth of $2 \mathrm{~nm}$ and integration time of 1-2 $\mathrm{s}$. Compounds in the range of concentration $10.6 \mu \mathrm{M}$ to $100 \mu \mathrm{M}$ were dissolved in a DMSO/Tris- $\mathrm{HCl}$ solution ( $5 \mathrm{mM}$ Tris- $\mathrm{HCl}, 50 \mathrm{mM} \mathrm{NaCl}, \mathrm{pH} 7.2)$ and added to the CT DNA $(100 \mu \mathrm{M})$ in a Tris- $\mathrm{HCl}$ buffer. The reference sample was a Tris- $\mathrm{HCl}$ buffer. The DMSO content in the solutions was $<2 \%$.

\subsection{Antibacterial Activity}

The antimicrobial activity of the CuHABH, HABH, and HESP were tested against Gram-positive bacteria: Staphylococcus aureus ATCC25923, Staphylococcus aureus ATCC27734, Listeria monocytogenes ATCC 19111, and Listeria monocytogenes ATCC 19115; and Gram- 
negative bacteria: Salmonella Choleraesuis ATCC 7001, Salmonella Typhimurium ATCC 14028, and Escherichia coli ATCC 10536. The strains were activated from cryobanks by passaging twice onto a nutrient broth (Merck, Darmstadt, Germany). Bacteria S. aureus ATCC25927, S. aureus ATCC27734, S. Choleraesuis ATCC 7001, S. Typhimurium ATCC 14028 and E. coli ATCC 10536 were grown for $24 \mathrm{~h}$ at $37^{\circ} \mathrm{C}$ while L. monocytogenes ATCC 19111, and L. monocytogenes ATCC 19115 were cultured for the same time at $30^{\circ} \mathrm{C}$. Testing of antagonistic activity was performed according to the procedures recommended by the European Committee on Antimicrobial Susceptibility Testing EUCAST [43]. The inoculum suspension was prepared by selecting several colonies from overnight growth on the nutrient agar (Merck, Darmstadt, Germany) medium with a sterile loop and suspending the colonies in a sterile saline $(0.9 \% \mathrm{w} / \mathrm{v} \mathrm{NaCl}$ in water) to the density of $0.5 \mathrm{McF}$ arland standard $\left(1-2 \times 10^{8} \mathrm{CFU} / \mathrm{mL}\right)$. The samples of the test compounds were dissolved in DMSO to obtain a concentration of $5 \mathrm{mg} / \mathrm{mL}$ and were sterilized by filtration (filter pore width $0.2 \mu \mathrm{m}$; (Sartorius AG, Gottingen, Germany). Paper disks $(\varnothing=6 \mathrm{~mm}$, Oxoid, (Thermo Fisher Scientific, Waltham, MA, USA)) were impregnated with compound samples, to obtain a concentration of the test compounds of $0.1 \mu \mathrm{M}$ per disk, and the solvent was allowed to evaporate in the dark at room temperature. A sterile cotton swab was dipped into the inoculum bacterial suspension and the excess fluid removed by turning the swab against the inside of the tube to avoid over-inoculation of the plates. The inoculum was spread evenly over the entire surface of the agar plate by swabbing in three directions. The bacteria inoculum test culture smear was on sterile Mueller-Hinton Agar (Merck, Darmstadt, Germany) plates. The impregnated paper disks were placed on the plates' surface. DMSO solution was used as a negative control at the concentration of $20 \mathrm{mg} / \mathrm{mL}$ (this concentration of DMSO did not inhibit the growth of microorganisms) [44]. The vancomycin (Oxoid Thermo Fisher Scientific, Waltham, MA, USA) was used as the positive control for the Grampositive bacteria, ampicillin (Oxoid Thermo Fisher Scientific, Waltham, MA, USA) for the Gram-negative bacteria. The plates were incubated at the above-mentioned temperatures for 16-24 h. After the incubation time, the zone inhibition of the bacteria growth was measured. The experiments were performed in two independent replications. The results were expressed in average values and standard deviation. The results were analyzed using a one-way analysis of variance (ANOVA) $p \leq 0.05$.

\subsection{Antibiofilm Activity}

The following compounds were under investigation: $\mathrm{HABH}\left(10^{-4} \mathrm{M} / \mathrm{mL}\right), \mathrm{CuHABH}$, $\left(10^{-4} \mathrm{M} / \mathrm{mL}\right)$, Hesperetin $\left(10^{-4} \mathrm{M} / \mathrm{mL}\right)$ and DMSO. The concentration of $3 \times 10^{-4} \mathrm{M} / \mathrm{mL}$ was used for all tested compounds. The growth and adhesion abilities of the bacterial strains in the presence of the tested compounds was carried out following previously published methods [45]. For the bacterial cultivation, the minimal medium of 50-fold diluted buffered peptone water (Merck, Darmstadt, Germany) was used because, according to the literature, biofilm formation may be stimulated in environments poor in carbon sources [46]. In this culture medium, the availability of the organic compounds was very limited and equal $0.1 \mathrm{~g} / \mathrm{L}$ [45]. The sterile minimal medium was poured into sterile $25 \mathrm{~mL}$ Erlenmeyer flasks, into which sterile glass carriers (Star Frost $76 \times 26 \mathrm{~mm}$, Knittel Glass, Braunschweig, Germany) were placed vertically in such a way that half of the carrier was immersed in the medium while the other part remained outside. The amount of bacterial inoculum was standardized densitometrically in McFarland degrees [ $\left.{ }^{\circ} \mathrm{McF}\right]$ to obtain a cell concentration in the culture medium approximately equal to $5 \times 10^{3}-1 \times 10^{4} \mathrm{CFU} / \mathrm{mL}$ at the start of each experiment. The samples were incubated at a temperature of $25^{\circ} \mathrm{C}$ on a laboratory shaker (135 rpm) for 6 days. Growth of the bacterial cultures was evaluated in ${ }^{\circ} \mathrm{McF}$ using a densitometer DEN-1 (Merck, Darmstadt, Germany). In turn, analysis of the bacterial adhesion to the glass carriers was performed using luminometry. For the luminometric tests, the carrier was removed from the culture medium, rinsed with sterile distilled water and swabbed using free ATP sampling pens (Merck, Darmstadt, Germany). The measurements were reported in RLU $/ \mathrm{cm}^{2}$ using a HY-LiTE 2 luminometer 
(Merck, Darmstadt, Germany). These experiments were conducted in triplicate, and the standard deviation was calculated. In addition, the bacterial attachment was observed using fluorescence microscopy (Nikon) after DAPI staining.

\section{Results and Discussion}

3.1. Characterization of the Complex $\mathrm{CuHABH}$

3.1.1. IR Spectral Studies

IR spectra provided substantial and valuable information on the coordination reaction. All the spectra recorded were characterized by vibrational bands mainly due to the $\mathrm{NH}, \mathrm{O}-$ $\mathrm{H}, \mathrm{C}=\mathrm{O}$ and $\mathrm{C}=\mathrm{N}$ groups (Figure S7). The IR spectrum of the Schiff base ligand $\mathrm{HABH}\left(\mathrm{LH}_{3}\right)$ showed a broad band at $3421 \mathrm{~cm}^{-1}$ due to phenolic $\mathrm{OH}$ and medium intensity weak bands at $3333 \mathrm{~cm}^{-1}$ due to-amide NH. The strong bands of high intensity observed at $1630 \mathrm{~cm}^{-1}$, $1609 \mathrm{~cm}^{-1}$ and $1253 \mathrm{~cm}^{-1}$ were due to the carbonyl function $v(\mathrm{C}=\mathrm{O})$, azomethine function $v(\mathrm{C}=\mathrm{N})$ and phenolic function $(\mathrm{C}-\mathrm{O})$, respectively. The IR spectra of the metal complex exhibited ligand bands with the appropriate shifts due to a complex formation. It was observed in the $\mathrm{CuLH}_{2}(\mathrm{OAc})$ spectrum an absence of stretching vibration due to phenolic $\mathrm{OH}$ at $3421 \mathrm{~cm}^{-1}$. This may indicate the formation of a coordination bond between the metal ion and phenolic oxygen atom at C5 (Figure S7) via deprotonation. This was further confirmed by the increase of absorption frequency of phenolic $v(C-O)$ of about $25 \mathrm{~cm}^{-1}$ which appeared in the region $1278 \mathrm{~cm}^{-1}$ of the complex, indicating the participation of an oxygen atom of the phenolic $\mathrm{OH}$ in the coordination. The band assigned to the $\mathrm{OH}$ group did not completely disappear, and it was probably merged with the NH band.

In the spectrum of the metal complex a medium intensity weak band of $v(\mathrm{NH})$ at $3395 \mathrm{~cm}^{-1}$ was shifted to higher frequencies $\Delta v=62 \mathrm{~cm}^{-1}$ in comparison to a small and sharp vibration in the ligand. The amine group did not take part in the formation of the coordination bond with the copper, which was confirmed in EPR studies. The change of the band shape of $v(\mathrm{NH})$ in the complex was probably due to the merging of the $\mathrm{OH}$ and NH bands.

The position of the amide carbonyl frequency $v(\mathrm{C}=\mathrm{O})$ in the spectrum of the copper complex observed at $1613 \mathrm{~cm}^{-1}$ was shifted to a lower frequency by approximately $17 \mathrm{~cm}^{-1}$ compared to that of the ligand. This indicates the participation of oxygen from the $\mathrm{CO}$ group of the amide in the coordination of copper ions [47]. The stretching frequency of the $\mathrm{C}=\mathrm{N}$ group in the copper(II) complex observed at $1593 \mathrm{~cm}^{-1}$ was shifted to a lower wavenumber compared to that of the ligand observed at $1609 \mathrm{~cm}^{-1}$.

The results clearly indicate the coordination of a copper ion through the $\mathrm{N}$ atom of the azomethine group of the HABH Schiff base [48]. The presence of acetate anions in the complex was confirmed by the bands of stretching vibrations $v(\mathrm{COO}-)$ at the frequencies of 1563 and $1362 \mathrm{~cm}^{-1}$. Coordination of the metal ion with the ligand was additionally confirmed by the appearance in the spectrum of the complex of new, non-ligand bands of weak intensity in the regions of $445 \mathrm{~cm}^{-1}$ and $410 \mathrm{~cm}^{-1}$ assigned to the stretching vibrations $v(\mathrm{M}-\mathrm{O})$ and $v(\mathrm{M}-\mathrm{N})$, where $\mathrm{M}$ is a metal ion, respectively.

\subsubsection{EPR Spectral Studies in Solid State and Solution}

The EPR spectra of the solid complex $\mathrm{CuHABH}$ (or $\left[\mathrm{CuLH}_{2}(\mathrm{OAc})\right]$ ) were recorded on the polycrystalline powder at $298 \mathrm{~K}$ (room temperature, RT) and $77 \mathrm{~K}$ (liquid nitrogen temperature, LNT) and after dissolving the compound in DMSO and DMF at $77 \mathrm{~K}$. The spectra, reported in Figure 2, were countersigned by a tetragonal signal. The resolution improved with decreasing the temperature, and at LNT (liquid nitrogen temperature) the hyperfine coupling between the unpaired electron and the ${ }^{63,65} \mathrm{Cu}$ nucleus clearly emerges (Figure 2b). 


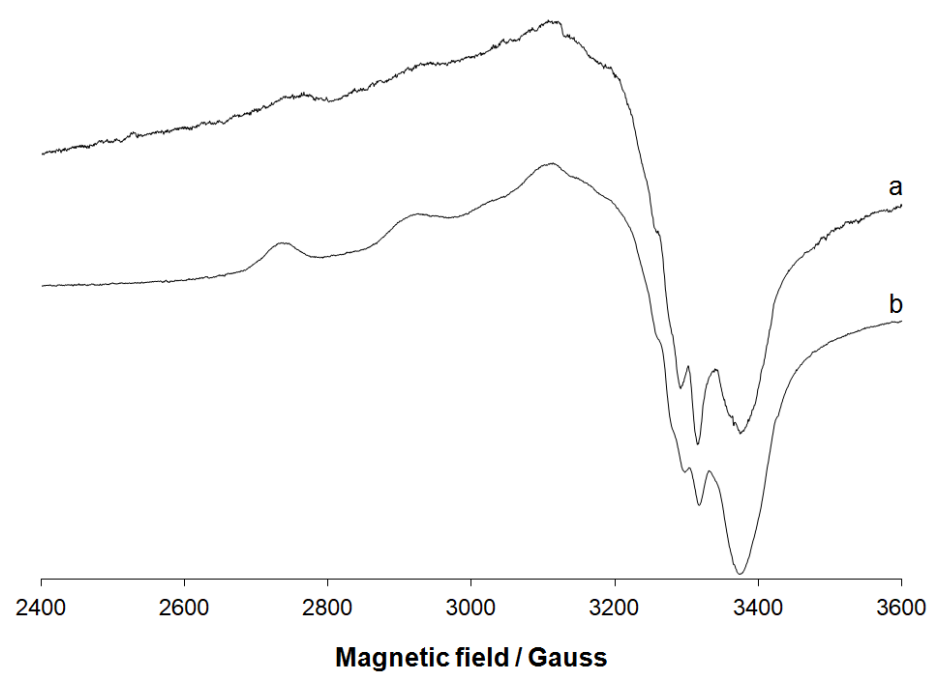

Figure 2. EPR spectra recorded on the polycrystalline powder of [ $\left.\mathrm{CuLH}_{2}(\mathrm{OAc})\right]$ : (a) $298 \mathrm{~K}$ and (b) $77 \mathrm{~K}$.

To improve the resolution, the solid compound was dissolved in an organic solvent and the spectra were recorded on the solution (Figure S8). In DMF and DMSO, the features due to the hyperfine coupling were well visible and allowed us to fully characterize the structure of the complex. The EPR spectrum was assigned to only one species with $g_{z}=2.240-2.241$ and $\left|A_{\mathrm{z}}\right|=192.5-194.0 \times 10^{-4} \mathrm{~cm}^{-1}$. The spin Hamiltonian parameters (Table 1) were extracted generating the experimental spectrum with WinEPR SimFonia software [25]. The value of $g_{\mathrm{z}}$ and $A_{\mathrm{z}}$ fell in the expected range for an equatorial coordination $\mathrm{Cu}\left(\mathrm{NO}_{3}\right)$ [49]. The order $g_{z} \gg>g_{\mathrm{x}} \sim g_{\mathrm{y}}>g_{\mathrm{e}}$ indicates a tetragonal symmetry with a small rhombicity degree and a ground state based on the $\mathrm{Cu}-d_{\mathrm{x} 2-\mathrm{y} 2}$ orbital [50]. In correspondence with the first resonance of the parallel region, the superhyperfine coupling with one nucleus of ${ }^{14} \mathrm{~N}\left(A^{\mathrm{N}}\right)$ with $I=1$ was revealed (region amplified in Figure S8). The quartet detected showed an experimental intensity ratio of 1:3:3:2 which can be explained with the overlap of the two triplets with an approximate ratio of 1:1:1 and 2:2:2 due to the presence in the natural copper of the isotopes ${ }^{63} \mathrm{Cu}\left(69.2 \%\right.$ natural abundance) and ${ }^{65} \mathrm{Cu}(30.8 \%)$. A detailed explanation of the origin of this multiplet is given in ref. [17]. The value of $16.0 \times 10^{-4} \mathrm{~cm}^{-1}$ for $A^{\mathrm{N}}$ was in good agreement with those reported in the literature up till now [51-54]. Summarizing these findings and the data of the elemental analysis, the results suggest that a tetracoordinate complex with square planar geometry is formed in the solid state with two oxygen and one nitrogen donors of the ligand occupying three equatorial positions, while an oxygen of an acetate ion completes the equatorial plane of the copper(II) ion.

Table 1. Experimental and calculated spin Hamiltonian parameters of $\left[\mathrm{CuLH}_{2}(\mathrm{OAc})\right]$.

\begin{tabular}{ccccccccc}
\hline Species & $g_{\mathbf{x}}$ & $g_{\mathbf{y}}$ & $g_{\mathbf{z}}$ & $\mathbf{P D}\left(g_{\mathbf{z}}\right)^{\mathbf{a}}$ & $A_{\mathbf{x}}(\mathbf{C u})^{\mathbf{b}}$ & $A_{\mathbf{x}}(\mathbf{C u})^{\mathbf{b}}$ & $A_{\mathbf{x}}(\mathbf{C u})^{\mathbf{b}}$ & $\mathbf{P D}\left(A_{\mathbf{z}}\right)^{\mathbf{a}}$ \\
\hline Powder & $\mathrm{C}$ & $\mathrm{c}$ & 2.232 & -1.0 & $\mathrm{c}$ & $\mathrm{C}$ & -193.4 & 3.9 \\
DMF & 2.040 & 2.060 & 2.240 & -1.4 & -11.0 & -14.0 & -192.5 & 4.4 \\
DMSO & 2.038 & 2.061 & 2.241 & -1.4 & -12.0 & -13.0 & -194.0 & 3.6 \\
$\begin{array}{c}\text { Aqueous } \\
\text { solution }{ }^{\mathrm{d}}\end{array}$ & 2.039 & 2.061 & 2.245 & -1.6 & -11.5 & -13.0 & -188.8 & 6.4 \\
$\begin{array}{c}\text { DFT } \\
\text { calculated }\end{array}$ & 2.061 & 2.062 & 2.209 & - & -7.7 & -18.5 & -200.9 & - \\
\hline
\end{tabular}

a Percent deviation of the DFT calculated parameter from the experimental value. ${ }^{\mathrm{b}}$ Hyperfine coupling constant reported in $10^{-4} \mathrm{~cm}^{-1}$ units. c Parameter not measurable from the experimental spectrum. ${ }^{\mathrm{d}}$ Species detected at $\mathrm{pH} 8.05$ with $\mathrm{Cu}(\mathrm{II}) / \mathrm{HABH}\left(\mathrm{H}_{3} \mathrm{~L}\right)$ ratio of $1: 1$ and $\mathrm{Cu}(\mathrm{II})$ concentration of $1.0 \times 10^{-3} \mathrm{M}$. ${ }^{\mathrm{e}}$ The $g$ and $A$ tensors calculated by DFT methods at the level of theory PBE0/6-311g (d,p) (tensor $g$ ) and B3LYP/6-311g(d,p) (tensor $A$ ). 
The structure of the $\left[\mathrm{CuLH}_{2}(\mathrm{OAc})\right]$ species was optimized by DFT methods using the B3LYP functional coupled with the Grimme's D3 dispersion, and the basis set 6-311g(d,p) for the main group elements and SDD plus $f$-functions and pseudo-potential for the $\mathrm{Cu}$, following the procedure in the literature [37]. The structure is shown in Figure 3.

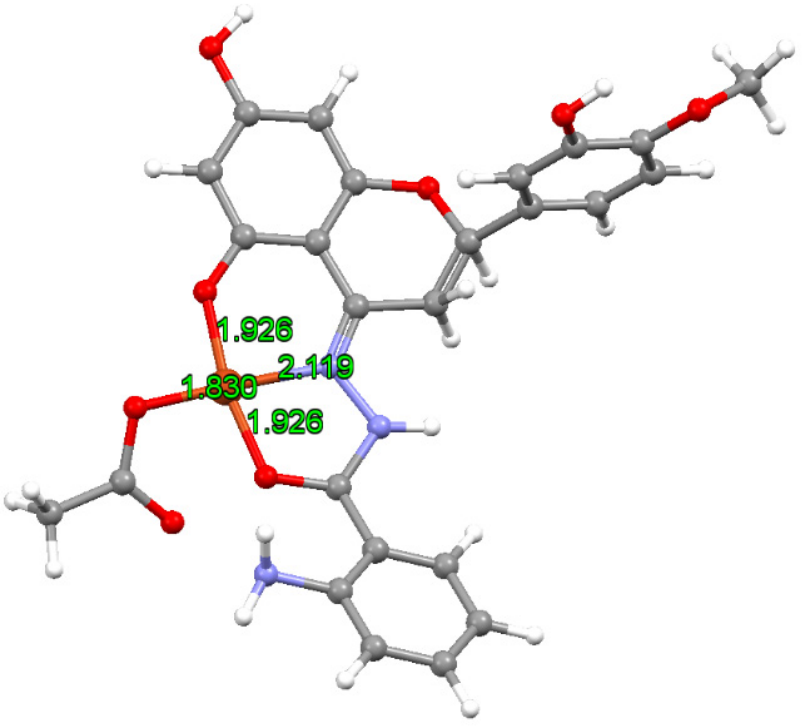

Figure 3. Optimized structure of $\left[\mathrm{CuLH}_{2}(\mathrm{OAc})\right]$. The distances of $\mathrm{Cu}$-donors are also shown (in $\AA$ ).

The $\mathrm{Cu}-\mathrm{O}$ distances were between $1.830 \AA$ and $1.926 \AA$, while the length of the $\mathrm{Cu}-\mathrm{N}$ was significantly larger (2.119 $\AA$ ). The structure showed a slight distortion from the regular square planar geometry with cis and trans angles in the range of $82.3-96.4^{\circ}$ and 168.5-177. ${ }^{\circ}$, respectively.

In addition, the EPR spectrum was calculated by the DFT protocol recently validated on fourteen $\mathrm{Cu}^{\mathrm{II}}$ complexes and, in particular, it was demonstrated that the mean absolute percent deviation (MAPD) in the prediction of $A_{z}$ with B3LYP functional was $8.6 \%$ with a standard deviation (SD) of $4.2 \%$, while the MAPD for the $g_{z}$ with PBE0 was $2.9 \%$ with a SD of $1.1 \%$ [37]. The results are listed in Table 1: the $g_{z}$ value is slightly underestimated with a percent deviation (PD) from the experimental data from $-1.0 \%$ to $-1.6 \%$, while the $A_{\mathrm{z}}$ is overestimated with a PD in the range of 3.6-6.4\%. These predictions are in line with the previous results in the literature [37,55]. Anisotropic EPR spectra were recorded in an aqueous solution containing ${ }^{63} \mathrm{CuSO}_{4} \cdot 5 \mathrm{H}_{2} \mathrm{O}$ and $\mathrm{HABH}\left(\mathrm{H}_{3} \mathrm{~L}\right)$ with a molar ratio of $1: 1$ and $\mathrm{Cu}(\mathrm{II})$ concentration of $1.0 \times 10^{-3} \mathrm{M}$ (Figure 3 ). After the formation of aquation $\left[\mathrm{Cu}\left(\mathrm{H}_{2} \mathrm{O}\right)_{6}\right]^{2+}$, the complexation process started around $\mathrm{pH} 4.0-4.5$ and two major species were detected in the solution, indicated with I and II in Figure 4. The spin Hamiltonian parameters for I were $g_{z}=2.373$ and $A_{z}=150.6 \times 10^{-4} \mathrm{~cm}^{-1}$, that differed little from those of the $\left[\mathrm{Cu}\left(\mathrm{H}_{2} \mathrm{O}\right)_{6}\right]^{2+}\left(\right.$ aq in Figure $4, g_{\mathrm{z}}=2.411$ and $\left.A_{\mathrm{z}}=135.3 \times 10^{-4} \mathrm{~cm}^{-1}\right)$. A comparison with $g_{z}$ and $A_{z}$ for the ( $\left.\mathrm{NH}_{2}, \mathrm{CO}\right)$ coordination (2.313-2.328 and 153-164 $\times 10^{-4} \mathrm{~cm}^{-1}$ [56]) indicated that the donor set for I could be (imine-N, CO). The species II, formed above pH 7, was characterized by $g_{\mathrm{z}}=2.245$ and $A_{\mathrm{z}}=188.8 \times 10^{-4} \mathrm{~cm}^{-1}$, comparable to the parameters measured for the solid compound dissolved in the DMSO and DMF (Table 1). These values were also similar to the $g_{z}$ and $A_{z}$ detected for the hesperetin Schiff base, which had the same equatorial coordination [17]. 


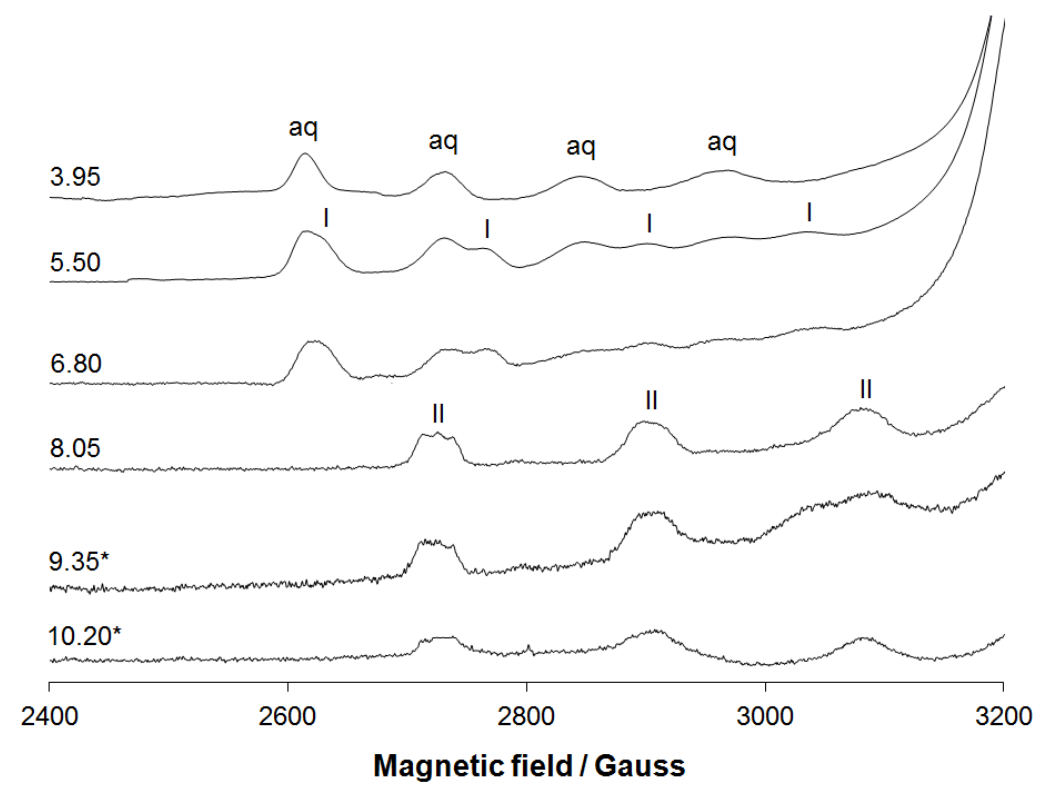

Figure 4. Low field region of the $\mathrm{X}$-band anisotropic EPR spectra recorded at $77 \mathrm{~K}$ as a function of $\mathrm{pH}$ in an aqueous solution containing ${ }^{63} \mathrm{CuSO}_{4} \cdot 5 \mathrm{H}_{2} \mathrm{O}$ and $\mathrm{HABH}\left(\mathrm{LH}_{3}\right)$ with a molar ratio of 1:1 and $\mathrm{Cu}(\mathrm{II})$ concentration of $1.0 \times 10^{-3} \mathrm{M}$. The values of $\mathrm{pH}$ are shown for each spectrum. The asterisk indicates that at $\mathrm{pH} 9.35$ and 10.20 the solution was opalescent for the presence of the solid compound. With aq, I and II the first parallel resonances of aquation, and of the complexes with coordination (imine- $\mathrm{N}, \mathrm{CO})$ and $\left(\mathrm{O}^{-}\right.$, imine- $\left.\mathrm{N}, \mathrm{CO}\right)$ are denoted.

The comparison of the spectra recorded on the solid compound dissolved in DMSO and on the aqueous solution containing ${ }^{63} \mathrm{CuSO}_{4} \cdot 5 \mathrm{H}_{2} \mathrm{O}$ and $\mathrm{HABH}$ (in the form of $\mathrm{LH}_{3}$ ) with a molar ratio of $1: 1$ at $\mathrm{pH} 8.05$ suggests that the two species share the same coordination mode (Figure S9). This implies that in the [CuHABH] species, revealed by potentiometry in the $\mathrm{pH}$ range 6.5-9.5, the ligand binds $\mathrm{Cu}$ (II) in the tridentate form with the donor set $\left(\mathrm{O}^{-}\right.$, imine- $\left.\mathrm{N}, \mathrm{CO}\right)$, similar to that observed in the solid state for the $\left[\mathrm{CuLH}_{2}\right]^{+}$(Figure 3). The deprotonation of the last non-coordinating $3^{\prime}-\mathrm{OH}$ group would give the species [CuL] ${ }^{-}$, as suggested by potentiometry (Figure S5), with the same coordination mode and, consequently, the same spin Hamiltonian parameters. The spectra obtained using the isotope ${ }^{63} \mathrm{Cu}$, moreover, allowed us to confirm the binding of only one nitrogen donor to the copper. In fact, the first parallel resonance at the lowest magnetic field showed only three resonances with the intensity ratio 1:1:1 expected for the coupling of the unpaired electron with one ${ }^{14} \mathrm{~N}$ nucleus. The values for $A^{\mathrm{N}}$ was $15.6 \times 10^{-4} \mathrm{~cm}^{-1}$, comparable with those measured upon dissolution of the solid $\mathrm{CuHABH}$ in an organic solvent and with those reported in the literature [51-54].

\subsection{Interaction of the Compounds with CT DNA}

The binding affinity of the complexes with DNA may provide the basis for a number of potential biomedical applications targeting the destruction of bacteria. The interaction of HESP, HABH and CuHABH with CT DNA was investigated by UV-Vis spectroscopy, via competitive studies with TO monitored by fluorescence emission spectroscopy and $\mathrm{CD}$ spectroscopy. Electronic absorption spectroscopy was a preliminary and important technique to investigate the binding mode and the strength of the compounds with the CT DNA, through titration and the calculation of the DNA-binding constant $\left(K_{b}\right)$ [57]. The CT DNA binding studies concerned the recording of the UV spectra of the CT DNA in the presence of increasing amounts of compounds (for different $r=$ [complex]/[CT DNA]). The binding was usually accompanied by noticeable changes in UV-is absorbance. During the titration, any change(s) in the band of CT DNA at $258-260 \mathrm{~nm}$, in the charge transfer or intraligand band(s) of the compounds, may indicate the existence of some kind of 
interaction [58]. UV-Vis titrations of all the three compounds with CT-DNA were performed in a Tris- $\mathrm{HCl}(\mathrm{NaCl})$ buffer ( $\mathrm{pH} 7.2)$.

The absorption profiles of the HESP and HABH showed two absorption bands $\lambda_{\max }=288,323 \mathrm{~nm}$ and $\lambda_{\max }=285,330 \mathrm{~nm}$, respectively, and the CuHABH complex exhibited one absorption band at $\lambda_{\max }=371 \mathrm{~nm}$ (Figure S10A). The bands at the longer wavelength may be attributed to intraligand or metal-induced charge transfer bands. Generally, the transfer bands are environmentally sensitive so, it was expected that these bands would show substantial changes in the presence of biological and bio-mimicking diverse microenvironments. It was found that the HESP showed a hyperchromic shift whereas the $\mathrm{HABH}$ and $\mathrm{CuHABH}$ showed a hypochromic shift with increasing concentration of the CT-DNA (Figure S10B, Table 2). Slight hyperchromism in the absorption band of the HESP at $323 \mathrm{~nm}$ may indicate DNA minor groove interactions $[59,60]$. On the other hand, significant hypochromism of the HABH and CuHABH (Figure S10B, Table 2) in the presence of double helical DNA was characteristic of the interactions between DNA and the molecule, which was due to the strong stacking interaction between the aromatic chromophore and the base pairs. Hence, it can be considered that there were some interactions between the $\mathrm{HABH}, \mathrm{CuHABH}$ and the DNA.

Table 2. UV-Vis spectral parameters of the interaction of HESP, HABH and CuHABH with CT DNA.

\begin{tabular}{cccc}
\hline Compound & $\boldsymbol{K}_{\boldsymbol{b}}\left[\mathbf{M}^{-\mathbf{1}}\right]$ & $\boldsymbol{\lambda}_{\max }[\mathbf{n m}]$ & $\begin{array}{c}\left(A_{\text {free }}-A_{\text {bound }}\right) / A_{\text {free }}[\%]_{\max } \\
(+) \text { Hyperchromism/ } \\
(-) \text { Hypochromism }\end{array}$ \\
\hline HESP & $1.20( \pm 0.15) \times 10^{4}$ & 323 & +5.57 \\
HABH & $4.00( \pm 0.22) \times 10^{5}$ & 330 & -41.78 \\
CuHABH & $5.00( \pm 0.18) \times 10^{5}$ & 371 & -56.52 \\
\hline
\end{tabular}

The coupling $\pi$ orbital was partially filled by electrons, thus decreasing the transition probabilities and concurrently resulting in hypochromism [61]. On the other hand, according to the literature reports, hypochromism indicates a strong interaction between the electronic states of the chromophore and that of DNA bases. As the decrease in the strength of the electronic interaction was expected as the cube of the distance between the chromophore and the DNA bases [62], the observed large hypochromism in our experiment strongly suggests a close adjacency of the $\mathrm{HABH}$ and especially the $\mathrm{CuHABH}$ to the DNA bases.

The absence of an isosbestic point in the absorption spectra was indicative of more than one type of binding interaction between the complexes and the CT-DNA. The binding constants were calculated for the interaction of the compounds with the CT-DNA using the Wolfe-Shimer equation (Equation (1)). From the plots of $[D N A] /\left(\varepsilon_{a}-\varepsilon_{f}\right)$ vs. [DNA] (Figure S10A, inset), linear relationships were acquired. The intrinsic binding constants $\left(K_{b}\right)$ were calculated from the ratio of the slope and intercept. They showed the following trends: $K_{b}{ }^{\mathrm{CuHABH}}>K_{b} \mathrm{HABH}>K_{b} \mathrm{HESP}$. The values were in conformity with the observed trend in hypochromism (Table 2). This result indicates that the extent of interaction of the $\mathrm{HABH}$ or CuHABH was much greater than that of the HESP, and in turn the CuHABH exhibited a greater effect compared to the HABH suggesting its higher propensity for DNA binding. The high binding constant $\left(K_{b}\right)$ for the complex may be attributed to steric hindrance imposed by the coordinated ligand. Lower values also indicated partial intercalative binding and/or surface binding of the compounds to the DNA.

To further clarify the binding mode of the complexes with the CT-DNA, TO competitive studies were carried out by fluorescence emission spectroscopy to examine whether the compounds tested can replace TO in the TO bounded CT-DNA system. Thiazole orange is composed of two heterocyclic ring systems (quinoline and benzothiazole) connected through a methine bridge (Figure 5). 


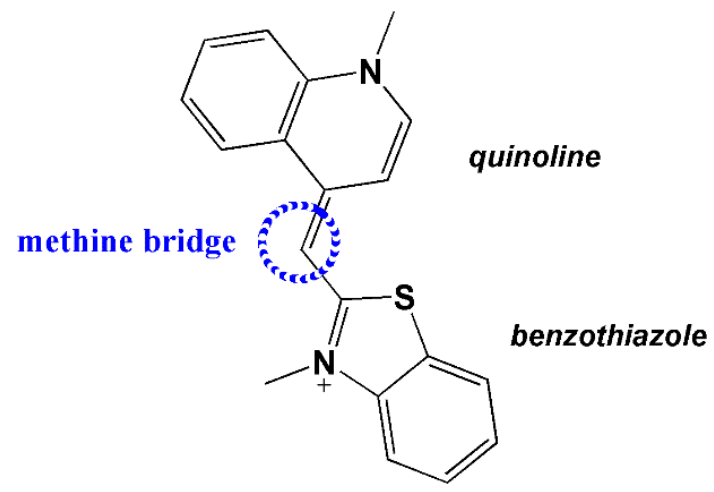

Figure 5. Structure of thiazole orange (TO).

The fluorescence intensity of the TO depends upon its conformation [63]. A planar state allows conjugation between the two aromatic systems-this is the fluorescent formwhereas rotation at the methine bridge produces a non-planar conformation, which is not fluorescent. In the presence of double stranded (ds) DNA, the TO acts as an intercalator (or groove binder) $[64,65]$. When intercalated, its fluorescent planar conformation is stabilized by stacking between base pairs [66]. The intercalating effect of the compounds was studied by adding stepwise a certain amount of their solution into a solution of the DNA-TO adduct. The impact of the addition of each compound to the DNA-TO adduct solution was obtained by monitoring the changes of the fluorescence emission spectra recorded with the excitation wavelength $\left(\lambda_{\text {ex }}\right)$ at $509 \mathrm{~nm}$ (Figure S11). The addition of the compounds induced moderate quenching of the fluorescence emission band of the DNA-TO adduct with respect to the HESP, or significant with respect to the $\mathrm{HABH}(70 \%)$ and $\mathrm{CuHABH}(90 \%)$ (Figure $\mathrm{S} 11 \mathrm{~B})$. The Stern-Volmer $\left(K_{S V}\right)$ and the quenching constants $\left(k_{q}\right)$ were determined using the Equations (2) and (3) (presented in Section 2). In turn, the values of the association constants $\left(K_{a}\right)$ and the number of binding sites $(n)$ were calculated on the base of the logarithmic Equation (4):

$$
\log \left(I_{0}-I / I_{0}\right)=\log K_{a}+n \log [Q]
$$

where $I_{0}$ and $I$ are fluorescence intensities of DNA-TO adduct in the absence and presence of the tested compounds, respectively, and [Q] compound concentration. The results are reported in Table 3 .

Table 3. TO-DNA fluorescence quenching parameters: Stern-Volmer constant $\left(K_{S V}\right)$, apparent constant $\left(K_{\text {app }}\right)$, quenching constant $\left(K_{q}\right)$, number of DNA binding sites $(n)$ and association constant $\left(K_{a}\right)$.

\begin{tabular}{ccccccc}
\hline Compound & $\boldsymbol{K}_{S V}\left[\mathbf{M}^{-\mathbf{1}}\right]$ & $\mathbf{C}_{\mathbf{5 0}}[\boldsymbol{\mu M}]$ & $\boldsymbol{K}_{\boldsymbol{a p p}}\left[\mathbf{M}^{-\mathbf{1}}\right]^{*}$ & $\boldsymbol{K}_{\boldsymbol{q}}\left[\mathbf{M}^{-\mathbf{1}}\right]$ & $\boldsymbol{n}^{*}$ & $\boldsymbol{K}_{\boldsymbol{a}}\left[\mathbf{M}^{-\mathbf{1}}\right]^{* *}$ \\
\hline Hesperetin & $3.73( \pm 0.06) \times 10^{3}$ & $\mathrm{nd}^{* * *}$ & $\mathrm{nd}^{* * *}$ & $1.43( \pm 0.20) \times 10^{12}$ & $0.55 \pm 0.04$ & $1.58( \pm 0.20) \times 10^{3}$ \\
HABH & $3.88( \pm 0.13) \times 10^{4}$ & 40.4 & $1.86 \times 10^{6}$ & $1.49( \pm 0.15) \times 10^{13}$ & $1.01( \pm 0.03)$ & $2.78( \pm 0.15) \times 10^{4}$ \\
CuHABH & $1.31( \pm 0.06) \times 10^{5}$ & 38.4 & $1.95 \times 10^{6}$ & $5.04( \pm 0.14) \times 10^{13}$ & $1.63( \pm 0.03)$ & $6.74( \pm 0.14) \times 10^{4}$ \\
\hline
\end{tabular}

${ }^{*} K_{a p p}=K_{\mathrm{TO}} \times\left[\mathrm{C}_{\mathrm{TO}}\right] /\left[\mathrm{C}_{50}\right]_{50 \%}$ intensity decrease; $\left[\mathrm{C}_{\mathrm{TO}}\right]=25 \mu \mathrm{M}, K_{\mathrm{TO}}=3.0 \times 10^{6}\left[\mathrm{M}^{-1}\right] .{ }^{* *} \log \left(I_{0}-I\right) / I_{0}=\log K_{a}+n \log [Q]$ $* * *$ nd-not determined in the range of tested concentrations.

The number of binding sites ranged from 0.55 for the HESP, 1.01 for the HABH to 1.63 for the $\mathrm{CuHABH}$ indicating the presence of a single binding site in the CT-DNA-TO adduct. The quenching constants were significantly higher than $10^{10} \mathrm{M}^{-1} \mathrm{~s}^{-1}$ suggesting that the quenching of the DNA-TO fluorescence induced from the compounds possibly took place via a static mechanism leading to the formation of a new adduct, obviously between the DNA and the HESP, HABH or CuHABH. This may confirm indirectly the TO-displacement and subsequently partial intercalation of the compounds to the CT DNA. Further, the apparent binding constant $\left(K_{a p p}\right)$ values were found for the compounds using the equation $K_{a p p}=K_{\mathrm{TO}} \times\left[\mathrm{C}_{\mathrm{TO}}\right] /\left[\mathrm{C}_{50}\right]$ (Table 3). The data suggest that the interaction of 
the CuHABH with CT-DNA was the highest one as compared to the HABH and HESP, which is consistent with the above absorption and emission spectral observations.

Since these changes indicate only one kind of quenching process, it may be concluded that all of the compounds bind to CT-DNA via a similar mode. Furthermore, such quenching constants and apparent binding constants of the ligand and $\mathrm{Cu}$ (II) complex (order of magnitude $10^{6}$ ) suggest that the interaction of the compounds with DNA should be mainly intercalation although other pathways of interaction (electrostatic, minor/major groove) cannot be excluded.

Circular dichroism spectroscopy is a useful tool for conformational investigation of the DNA helix. For this purpose, CD spectra of CT-DNA in the presence and absence of the $\mathrm{HABH}$ and $\mathrm{CuHABH}$ were recorded. These compounds were selected because of their stronger activity confirmed by electron absorption and emission spectroscopy. The CD spectrum of the bare DNA showed a positive band at $276 \mathrm{~nm}$ and a negative one at $242 \mathrm{~nm}$ which are the characteristic bands of the B-form of CT-DNA. In the case of groove binding or electrostatic binding, the $\mathrm{CD}$ spectrum showed almost no change, whereas the intercalative mode of binding affected both the positive and negative bands. With an increasing concentration of the $\mathrm{HABH}$, the ellipticity of the positive band increased and that of the negative band decreased to a large extent (Figure 6).

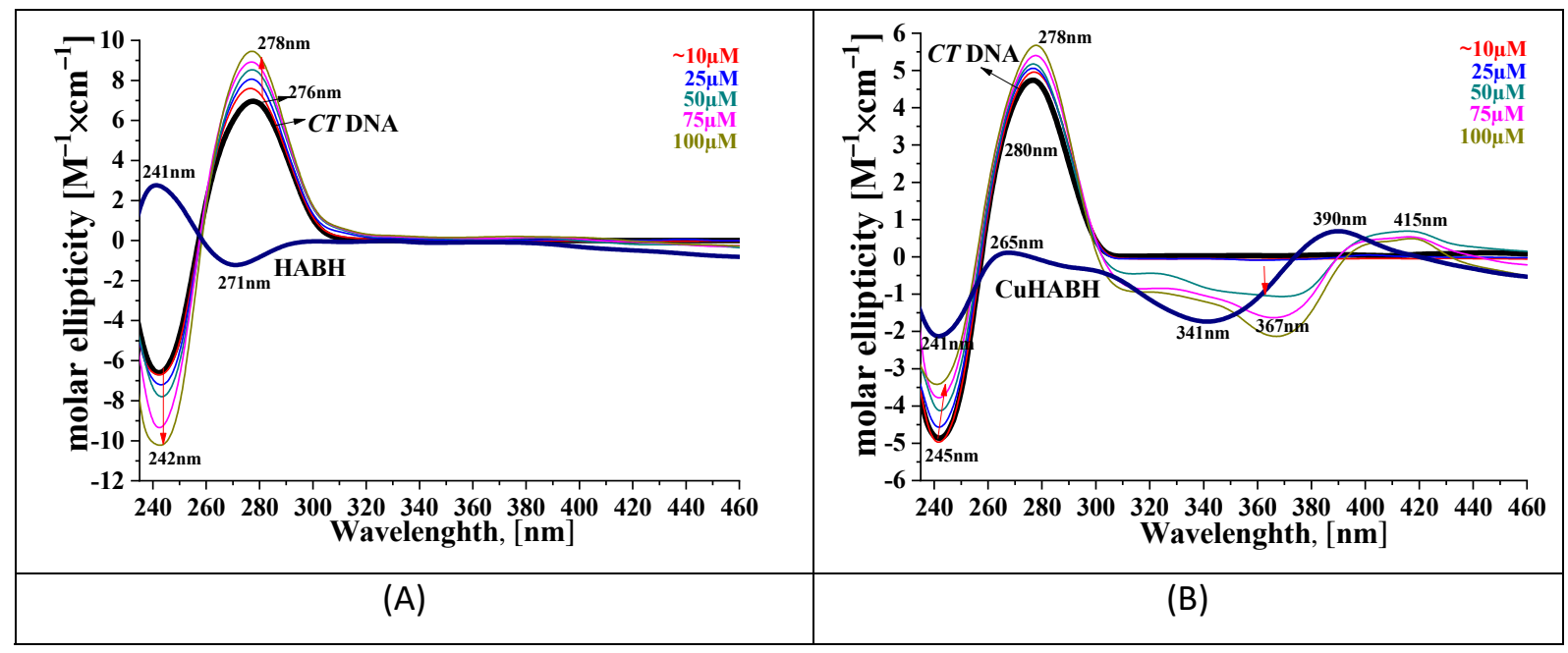

Figure 6. CD spectra of CT-DNA $(100 \mu \mathrm{M})$ in the presence of: (A) $\mathrm{HABH}$, and (B) $\mathrm{CuHABH}$ at 0-100 $\mu \mathrm{M}$ concentration. The red arrows indicate the direction of change/movement of the spectrum. The black arrows show the CT-DNA spectrum of DNA and its absorbance maximum. The numbers shown on the spectra refer to the absorbance maximum of the emerging bands.

In the positive band a red-shift $(2 \mathrm{~nm})$ was observed. In the case of the complex $\mathrm{CuHABH}$, the extent of change was the same in a positive band and opposite in a negative band (intensity increasing) in comparison to that of the $\mathrm{HABH}$, but in a narrow concentration range $(10-50 \mu \mathrm{M})$. Above the concentration of $75 \mu \mathrm{M}$ new bands appeared at 367 and $415 \mathrm{~nm}$. Their occurrence was most likely related to the formation of the CT-DNA-CuHABH adduct, which may have led to a drastic change in the spectrum of the CuHABH complex. The results indicate a stronger interaction between the $\mathrm{CuHABH}$ than the $\mathrm{HABH}$ with the CT-DNA. It can be assumed that the nature of the interactions was of the intercalating type, but in the high concentration range, the complex could bind DNA externally to phosphate residues or to a minor/major groove forming an adduct.

\subsection{Antibacterial Activity of the $\mathrm{HABH}$ and $\mathrm{C} U \mathrm{HABH}$ Complexes}

In vitro antibacterial screening of the ligand $\left(\mathrm{LH}_{3}\right)$ and the metal complex $\left[\mathrm{CuLH}_{2}(\mathrm{OAc})\right]$ was assayed against various bacterial strains and the potentiality of the compounds was evaluated by measuring the diameter of the zone of inhibition in $\mathrm{mm}$. The report of the 
antimicrobial results presented in Table 4 revealed that both the free ligand and its metal complex exhibited variable antimicrobial activity depending on the type of bacterial strain.

Table 4. Antimicrobial activity of selected compounds against some bacteria strains as diameter zone of inhibition.

\begin{tabular}{|c|c|c|c|c|c|c|c|}
\hline \multirow[b]{2}{*}{$\begin{array}{l}\text { Compound } \\
0.1 \mu \mathrm{M}\end{array}$} & \multicolumn{7}{|c|}{ Zone of inhibition [mm] } \\
\hline & $\begin{array}{c}\text { Salmonella } \\
\text { Choleraesuis } \\
\text { ATCC } 7001\end{array}$ & $\begin{array}{c}\text { Salmonella } \\
\text { Typhimurium } \\
\text { ATCC } 14028\end{array}$ & $\begin{array}{c}\text { Escherichia } \\
\text { coli } \\
\text { ATCC } 10536\end{array}$ & $\begin{array}{c}\text { Staphylococcus } \\
\text { aureus } \\
\text { ATCC } 25923\end{array}$ & $\begin{array}{c}\text { Staphylococcus } \\
\text { aureus } \\
\text { ATCC } 27734\end{array}$ & $\begin{array}{c}\text { Listeria mono- } \\
\text { cytogenes } \\
\text { ATCC } 19111\end{array}$ & $\begin{array}{c}\text { Listeria mono- } \\
\text { cytogenes } \\
\text { ATCC } 19115\end{array}$ \\
\hline CuHABH & $0.0 \pm 0.0^{\mathrm{aA}}$ & $0.0 \pm 0.0^{\mathrm{aA}}$ & $0.0 \pm 0.0^{\mathrm{aA}}$ & $10.5 \pm 0.50^{\mathrm{aA}}$ & $10.5 \pm 0.50^{\mathrm{aA}}$ & $0.0 \pm 0.0^{\mathrm{aA}}$ & $12.5 \pm 0.50^{\mathrm{aA}}$ \\
\hline $\mathrm{HABH}$ & $0.0 \pm 0.0 \mathrm{aA}$ & $0.0 \pm 0.0^{\mathrm{aA}}$ & $0.0 \pm 0.0^{\mathrm{aA}}$ & $11.5 \pm 0.50^{\mathrm{aA}}$ & $12.0 \pm 0.0^{\mathrm{bA}}$ & $0.0 \pm 0.0^{\mathrm{aA}}$ & $13.5 \pm 0.50^{\mathrm{bA}}$ \\
\hline HESP & $0.0 \pm 0.0^{\mathrm{aA}}$ & $0.0 \pm 0.0^{\mathrm{aA}}$ & $0.0 \pm 0.0^{\mathrm{aA}}$ & $9.0 \pm 0.0^{\mathrm{bA}}$ & $9.0 \pm 0.50^{\mathrm{cA}}$ & $0.0 \pm 0.0^{\mathrm{aA}}$ & $14.5 \pm 0.50^{\mathrm{cA}}$ \\
\hline DMSO & $0.0 \pm 0.0^{\mathrm{aA}}$ & $0.0 \pm 0.0^{\mathrm{aA}}$ & $0.0 \pm 0.0^{\mathrm{aA}}$ & $0.0 \pm 0.0^{\mathrm{cA}}$ & $0.0 \pm 0.0^{\mathrm{dA}}$ & $0.0 \pm 0.0^{\mathrm{aA}}$ & $0.0 \pm 0.0^{\mathrm{dA}}$ \\
\hline Vancomycin & $10.5 \pm 0.00^{\mathrm{B}}$ & $\mathrm{Nd}$ & $14.5 \pm 0.50^{\mathrm{B}}$ & $16.00 \pm 0.00^{\mathrm{B}}$ & $17.5 \pm 0.00^{\mathrm{B}}$ & $20.0 \pm 0.80^{B}$ & $30.5 \pm 0.50^{\mathrm{B}}$ \\
\hline Ampicillin & $\mathrm{Nd}$ & $12.60 \pm 0.90^{\mathrm{B}}$ & $\mathrm{Nd}$ & $\mathrm{Nd}$ & $\mathrm{Nd}$ & $21.0 \pm 0.80^{\mathrm{B}}$ & $16.5 \pm 0.50^{\mathrm{C}}$ \\
\hline
\end{tabular}

Vancomycin $(0.021 \mu \mathrm{M})$, Ampicillin $(0.006 \mu \mathrm{M})$-positive control. Nd-not determined. ${ }^{\text {a,b,c,d }}$ statistical differences within one microorganism. A,B,C statistical differences within one microorganism in relation to the positive test.

However, their activity is lower than that of standard antibiotics. The tested compounds showed variable activity against three Gram-positive bacteria (Staphylococcus aureus ATCC 25923, Staphylococcus aureus ATCC 27734 and Listeria monocytogenes ATCC 19115 isolation-human). The original hesperetin revealed the lowest inhibitory effect towards both strains of Staphylococcus aureus but the highest to Listeria monocytogenes ATCC 19115 as compared to the HABH and CuHABH (statistically significant). On the other hand, all Gramnegative bacteria (Salmonella Choleraesuis, Salmonella Typhimurium, and Escherichia coli) and one Gram-positive Listeria monocytogenes ATCC 19111 (isolation poultry) seem to be resistant to both ligands (HABH, HESP) and the complex (CuHABH) under the conditions of the measurements. The differences in the sensitivity to antagonistic factors of bacteria belonging to the same species may be manifold, e.g., the source of origin or differences consisting in different antigenic determinants located on the cell surface. Antigenic differences result from the presence of various chemical compounds, such as membrane proteins or lipoteichoic acid, which determine the structure of the cell membrane [67]. Considering the literature data, it can be assumed that there were a number of factors possibly affecting the response of the bacteria to the compounds tested in this study, including, diverse detoxification systems dependent on the bacteria strain or culture conditions that influenced the compounds' toxicity. These may change the cell surface composition of bacteria and thus reduce their viability [68].

In the case of Gram-negative bacteria used in these studies, no antagonistic activity of the tested compounds was found. This phenomenon may have resulted from the ability of the Gram-negative bacteria to create so-called outer membrane vesicles (OMV). OMVs play a special role in the physiology of Gram-negative bacteria. The creation of OMVs results in the encapsulation of stinging agents such as toxic substances inside the cell, preventing them from entering the cell. Thus, E. coli mutants showing very high levels of OMVs secretion have been shown to be resistant to polymyxin B compared to the wild-type strain [69]. Another example is the ability of the Pseusomonas aeruginosa to break down $\beta$-lactam antibiotics. P. aeruginosa strains in the presence of these antibiotics produce OMVs that contain enzymes that break down and inactivate $\beta$-lactam [70]; however, in order to confirm the above mechanism in our case, additional research is necessary.

There are many mechanisms of resistance to chemotherapeutic agents, but they are based on several major strategies. The most common are the production of enzymes that inactivate antibiotics, a blockade of antibiotic target receptors, changes in the permeability of the cell membrane and the mechanism of active removal of the antibiotic from the cell (efflux pump). The efflux pump mechanism is based on pumping out the chemotherapeutic agent, e.g., antibiotics, out of the cell [71]. The available literature describes studies on blocking the expression of efflux pomp proteins by bioactive compounds. The research group of Tintino et al. [72] demonstrated the inhibitory effect of tannic acid against efflux 
pumps expressed by the Staphylococcus aureus RN4220 and IS-58 strains. The efflux pump inhibition was assayed using a subinhibitory concentration of efflux pump standard inhibitors and tannic acid (MIC/8), observing their capacity to decrease the MIC of ethidium bromide and antibiotics due the possible inhibitory effect of these substances. In other studies, the effectiveness of inhibiting the efflux pump mechanism was also demonstrated in Staphylococcus aureus strains by caffeic and gallic acid (the MrsA pumps of the strain RN-4220 and NorA of the strain 1199B) [73], hydroxyamines derived from lapachol and norlachol (NorA pumps from the strain 1199B) [74], ferulic acid and its esterified derivatives (NorA pumps from the strain 1199B) [75]. In contrast, studies [76] have shown the activity of blocking the efflux pump by quercetin. Quercetin showed synergism with all antibiotics tested. In the association of this substance with ethidium bromide, there was a reduction of MICs in the strains carrying the TetK pump (from 16 to $2.51 \mu \mathrm{g} / \mathrm{mL}$ ) and NorA (from 64 to $12.69 \mu \mathrm{g} / \mathrm{mL}$ ), which shows the inhibition of these mechanisms.

\subsection{Antibiofilm Activity}

Bacterial adhesion to solid surfaces is a general phenomenon with relevance to numerous medical, industrial and ecological problems. Adhesion to inert materials, such as plastic and glass, has been recognized for several years as resulting from the physicochemical interactions between different components (microorganism, substrate and suspending medium) [77]. According to the XDLVO (Derjaguin, Landau, Verwey, and Overbeck) theory, the microbial adhesion is described as a balance between the Van der Waals, the electrostatic and the Lewis acid-base interactions (Figure 7) [78].

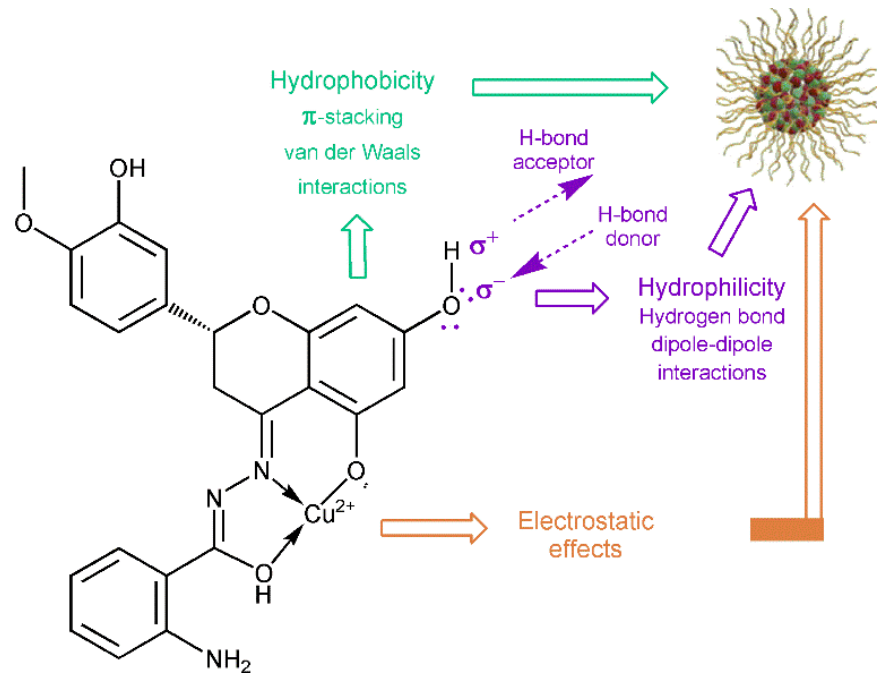

Figure 7. Proposed interactions of $\mathrm{CuHABH}$ complex with bacteria.

The magnitude of these interactions is affected by the distance of the bacterium from the surface and the ionic strength of the surrounding environment, but it is also necessary to take into account the structure of the bacterial cell wall which mediates the adhesion processes $[79,80]$. Therefore, in our studies, we used both Gram-positive and Gram-negative bacteria as the model microorganisms. Glass was selected for the experiments as a model surface because it is widely studied and most of its physicochemical properties are known and available in the literature [81]. Adhesion of bacterial cells to the glass surface is presented in Figure 8. 


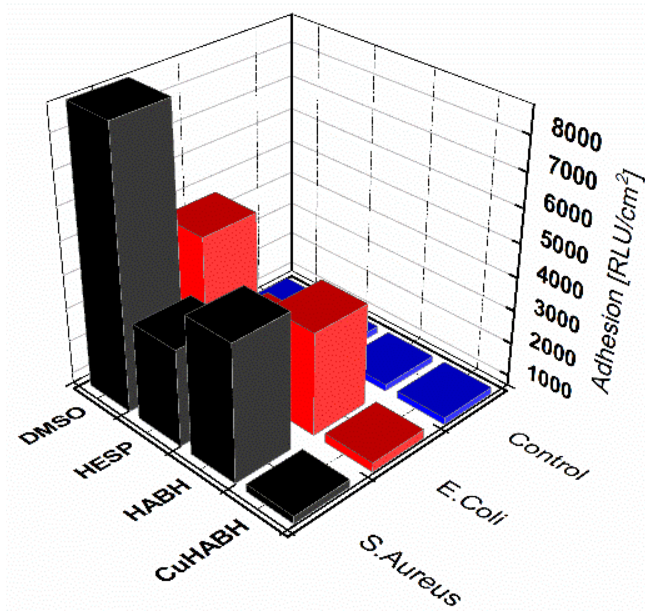

Figure 8. Adhesion [RLU $\left./ \mathrm{cm}^{2}\right]$ of bacterial strains to glass surface after 6-day incubation. DMSO (solvent); HESP (aglycone flavonoid); $\mathrm{HABH}$ (hesperetin hydrazone); $\mathrm{CuHABH}$ (complex $\mathrm{Cu}(\mathrm{II})$ with $\mathrm{HABH})$.

The highest levels of RLU corresponding to organic matter and ATP were recorded for the DMSO solution. The best antiadhesive action was detected for the $\mathrm{CuHABH}$ complex for both bacterial strains. This was confirmed in microscopic observations using fluorescence microscopy after DAPI staining [82] (Figure 9).

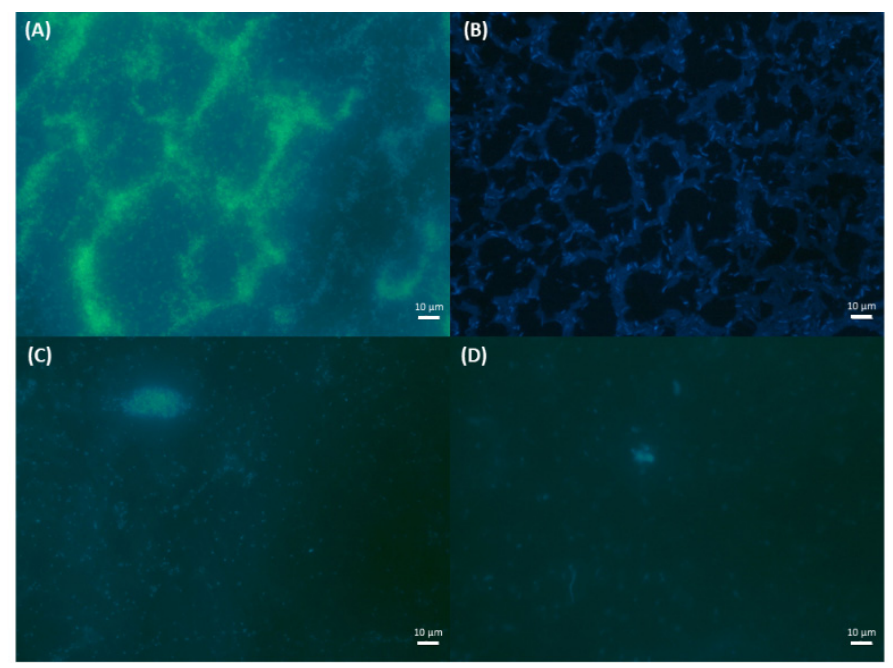

Figure 9. Adhesion of bacterial cells to glass surface after 6-day incubation and DAPI staining. (A) S. aureus and DMSO; (B) E.coli and DMSO; (C) S. aureus and CuHABH, and (D) E. coli and CuHABH. Bars represent $10 \mu \mathrm{m}$.

All tested compounds in the concentration $10^{-4} \mathrm{M} / \mathrm{mL}$ had antimicrobial and antibiofilm activity against both Gram-negative and Gram-positive bacteria. In inoculated and cultivated samples with the $\mathrm{HABH}, \mathrm{CuHABH}$ and HESP, growth of the bacterial strains was not detected densitometrically $\left[0^{\circ} \mathrm{McF}\right]$. Only in the culture media with the DMSO was very weak bacterial growth (very low turbidity) measured $\left[0.3^{\circ} \mathrm{McF}\right]$. Interestingly, the best action against biofilm formation was detected for the $\mathrm{Cu}-\mathrm{HABH}$. Metal-based nanoparticles are known from non-specific bacterial toxicity [83]. They do not bind to a specific receptor in the bacterial cell which not only makes the development of resistance by bacteria difficult, but also broadens the spectrum of antibacterial activity. Both Gram-positive and Gram-negative bacteria have a negatively charged surface, however, there are significant differences in the structure of the cell wall [84]. Gram-positive bacteria have a thick layer of peptidoglycan formed by linear chains of $\mathrm{N}$-acetylglucosamine and $\mathrm{N}$-acetylmuramic acid. 
On the other hand, Gram-negative bacteria, have a more complex structure with a thin layer of peptidoglycan and a phospholipid outer membrane with partially phosphorylated lipopolysaccharides contributing to increase the negative surface charge of a cell envelope. It has been documented that positively charged nanoparticles establish a strong bond with negatively charged bacterial membranes, resulting in the disruption of cell walls and increasing their permeability. In addition, nanoparticles can also release compounds from the extracellular space, capable of entering the cell and disrupting biological processes. Metal-based nanoparticles, due to their non-specific mechanisms of antimicrobial action, generally exhibit a broad spectrum activity [83,85].

Among the metal particles, copper compounds have been explored with great attention as antimicrobial and antibiofilm agents [86,87]. The effects of copper are multifaceted and include, for example, the destruction of iron-sulfur cluster proteins and metalloproteins, production of reactive oxygen species, and interference with membrane integrity. These mechanisms are possibly the key to the antibacterial action of this metal. It has been documented that copper compounds are proven to restrict the spread of epidemic methicillin-resistant $S$. aureus (MRSA) strains. Therefore, the nonselective nature of these copper-dependent processes poses a challenge for target-directed applications in antibacterial strategies [88]. The copper compounds also exhibit antibiofilm activity with the ability to disrupt pre-formed biofilms. In studies conducted by Brahma et al., hexadentated macrocyclic complex of copper(II) showed an increased susceptibility towards S. aureus and it was able to reduce more than $95 \%$ of the bacterial load at the concentration $10 \mu \mathrm{g} / \mathrm{mL}$ [89]. The strong inhibitory effect of $\mathrm{CuHABH}$ was also observed in our studies.

Furthermore, the presence of a flavonoid molecule may also affect the biofilm formation and quorum sensing phenomenon, but this mechanism is not fully understood [9]. It was documented that the administration of flavonoids to $P$. aeruginosa cultures alters the transcription of quorum sensing-controlled target promoters and suppresses virulence factor production. Recent researches show that flavonoids are able to inhibit biofilm formation by Streptococcus mutans [90], Aeromonas hydrophila [91], Candida albicans [92], S. aureus [93], and Escherichia coli O157:H7 [94] and persister cells formation in A. baumannii [95]. Flavonoids such as quercetin have the most potent antibiofilm property as they have the ability to inhibit DNA gyrase, bacterial energy metabolism and cell membrane function [96]. It has also been shown that aglycone flavonoids, including hesperetin, inhibit biofilm formation by $S$. aureus strains that overexpress efflux protein genes. These effects are more strongly established by aglycone flavonoids than their glycone [97]. This phenomenon was confirmed in our study. The hesperetin molecule exhibited more potent antibiofilm property than its hydrazone (modified molecule of hesperetin) in terms of the bacteria used as shown in Figure 8.

Summarizing, the CuHABH complex may play a crucial role in disrupting exopolymers in biofilm formation. Nevertheless, more research is needed to determine the mechanism of the action of $\mathrm{CuHABH}$ as a potential biocide.

\section{Conclusions}

In summary, the new derivative of hesperetin, HABH (2-amino- $\mathrm{N}^{\prime}-(2,3-$ dihydro-5,7dihydroxy-2-(3-hydroxy-4-methoxyphenyl)chromen-4-ylidene)benzohydrazide), and its copper complex, $\mathrm{CuHABH}$, were designed in order to investigate their antimicrobial and antibiofilm activities. Their structures both in a solid state and in solution were established using several methods: FT-IR, ${ }^{1} \mathrm{H}$ NMR, ${ }^{13} \mathrm{C}$ NMR, UV-Vis, FAB MS, EPR, ESI-MS and potentiometry. In the copper complex dominating at the physiological $\mathrm{pH}$ region, to which the potentiometry assigned the stoichiometry $\mathrm{CuLH}$ species, the ligand binds to $\mathrm{Cu}(\mathrm{II})$ in the tridentate form, with the donor set $\left(\mathrm{O}^{-}\right.$, imine- $\left.\mathrm{N}, \mathrm{CO}\right)$, analogous to that observed in the solid state for $\left[\mathrm{CuLH}_{2}\right]^{+}$. Furthermore, the interaction between $\mathrm{HABH}$ and $\mathrm{CuHABH}$ with calf-thymus DNA was investigated. The results indicate a stronger affinity of the $\mathrm{CuHABH}$ to the CT-DNA than the HABH. It can be assumed that if the copper complex penetrates the outer membrane of bacterial cells, it can disrupt/stop DNA or protein synthesis, which will 
result in limiting the growth of bacterial cells, enhancing the anti-adhesive effect against bacterial strains.

Hesperetin and its derivatives show a wide range of antimicrobial activity [9]. Antibacterial screening of the ligand and the metal complex was assayed against Gram-positive bacteria: Staphylococcus aureus ATCC25923, Staphylococcus aureus ATCC27734, Listeria monocytogenes ATCC 19111, and Listeria monocytogenes ATCC 19115 and Gram-negative bacteria: Salmonella Choleraesuis ATCC 7001, Salmonella Typhimurium ATCC 14028, and Escherichia coli ATCC 10536, and the potentiality of the compounds was evaluated by measuring the diameter of the zone of inhibition. The antagonistic activity of natural and synthetic bioactive compounds depends on the factor-strain test system. Very often these are individual interactions, which we observed within the tested Listeria monocytogenes strains; however, in the case of the strains of Gram-negative bacteria and the tested HABH or $\mathrm{CuHABH}$, bacterial resistance to these compounds was observed. Under the experimental conditions of this study, it is concluded that both the geometry and $\mathrm{Cu}$ presence may play an important role in antibiofilm activity. Among different compounds tested in this study, the $\mathrm{CuHABH}$ was the most effective antimicrobial material against both Gram-positive and Gram-negative bacteria. It diminished the adhesive action of bacteria. This molecule may play a crucial role in disrupting exopolymers (DNA/proteins) in biofilm formation. The CuHABH complex could be used to prevent bacterial adhesion especially on glass equipment. The present study had its own limitations as only the antibiofilm efficacy for two reference bacterial strains was assessed. The mechanism of interaction requires in-depth research to elucidate the phenomenon. Further studies are required to assess the impact of these compounds on wild bacterial strains isolated from various natural environments. It is evident from this work that the studied compounds, especially the $\mathrm{CuHABH}$ complex, may be efficient alternatives in the search for new forms of treatment against bacteria. The knowledge gained from the conducted research will be used in future studies, concerning the formation of nanocapsules of flavonoid derivatives with increased water solubility.

Our research should be considered significant; however, more research is needed to investigate the detailed antimicrobial and anti-biofilm effects of hesperetin and its derivatives. This compound, as well as other flavonoid structures, will always inspire research into the design and synthesis of new effective antimicrobials.

Supplementary Materials: Supplementary material associated with this article can be found in the online version. The following figures are available online, Figure S1. ${ }^{1} \mathrm{H}$ NMR $(400 \mathrm{MHz})$ spectrum of $\mathrm{HABH}$ in DMSO- $\mathrm{d}_{6}$ at $20{ }^{\circ} \mathrm{C}$. Figure S2. ${ }^{13} \mathrm{C}$ NMR (400 MHz) spectrum of HABH in DMSO- $\mathrm{d}_{6}$ at $20{ }^{\circ} \mathrm{C}$. Figure S3. Mass spectrum of the CuHABH complex. Figure S4. (A) Titration curves of $\mathrm{HABH}$ and $\mathrm{CuHABH}$ systems; (B) Species distribution curves for $\mathrm{HABH}$ and (C) $\mathrm{Cu}(\mathrm{II})-\mathrm{HABH}$ systems. Ligand $/$ metal $=1 / 1, \mathrm{C}_{\mathrm{L}}=5 \times 10^{-4} \mathrm{M} ; \mathrm{C}_{\mathrm{Cu}(\mathrm{II})}=5 \times 10^{-4} \mathrm{M}$. Figure S5. Proposed scheme of protonation/deprotonation equilibria during $\mathrm{pH}$-metric titration of $\mathrm{HABH}(\mathrm{A})$ and $\mathrm{CuHABH}(\mathrm{B})$. The charge of $\mathrm{Cu}$ ions is +2 in the proposed structure of complexes for simplicity it is omitted. Figure S6. Electronic absorption (UV-Vis) spectra recorded in DMSO/water mixture (30\%/70\% v/v fraction) at different $\mathrm{pH}$ corresponding to the dominant species in $\mathrm{HABH}$ or $\mathrm{CuHABH}$ systems. $\mathrm{C}_{\mathrm{HABH}}=\mathrm{C}_{\mathrm{CuHABH}}=1 \times 10^{-5} \mathrm{M}$. The values of $\mathrm{pH}$ are indicated next to the spectra. Figure S7. FT-IR spectra of ligand HABH and complex $\mathrm{CuHABH}\left(\left[\mathrm{CuLH}_{2}(\mathrm{OAc})\right]\right)$. Figure S8. EPR spectra recorded at $77 \mathrm{~K}$ on the polycrystalline powder of $\left[\mathrm{CuLH}_{2}(\mathrm{OAc})\right]$ dissolved in: (a) DMF and (b) DMSO. In the trace c the spectrum in DMSO, obtained with WinEPR SimFonia software, is reported; it was generated using $g_{\mathrm{x}}=2.038, g_{\mathrm{y}}=2.061, g_{\mathrm{z}}=2.241$, $A_{\mathrm{x}}(\mathrm{Cu})=-12.0 \times 10^{-4} \mathrm{~cm}^{-1}, A_{\mathrm{y}}(\mathrm{Cu})=-13.0 \times 10^{-4} \mathrm{~cm}^{-1}, A_{\mathrm{z}}(\mathrm{Cu})=-194.0 \times 10^{-4} \mathrm{~cm}^{-1}, A_{\mathrm{x}}\left({ }^{14} \mathrm{~N}\right)$ $=A_{\mathrm{y}}\left({ }^{14} \mathrm{~N}\right)=A_{\mathrm{z}}\left({ }^{14} \mathrm{~N}\right)=16.0 \times 10^{-4} \mathrm{~cm}^{-1}$. The first parallel resonance of the spectrum in DMSO is also shown amplifying the experimental signal three times. Figure S9. Anisotropic EPR spectra recorded at $77 \mathrm{~K}$ on: (a) system ${ }^{63} \mathrm{CuSO}_{4} \cdot 5 \mathrm{H}_{2} \mathrm{O}$ and $\mathrm{HABH}$ as $\mathrm{LH}_{3}$ protonated form in solution (molar ratio 1:1 and $\mathrm{Cu}^{\mathrm{II}}$ concentration of $1.0 \times 10^{-3} \mathrm{M}$ ) and (b) solid compound [CuLH $\mathrm{CuAc}_{2}(\mathrm{OAc})$ dissolved in DMSO. Figure S10. (A) Spectrophotometric titration of HESP, HABH, CuHABH with CT DNA solution $\left(C_{C T D N A}=0-63 \mu \mathrm{M} ; C_{\text {compound }}=25 \mu \mathrm{M}\right)$; the arrows show the direction of changes in the spectra. The inset represents the plot of $[D N A] /\left(\varepsilon_{a}-\varepsilon_{f}\right)$ vs. [DNA]. (B) Effect of test compound 
concentration on the absorption intensity of compound-CT DNA system. Figure S11. (A) Emission spectra of HESP, HABH and CuHABH with increasing concentration of CT DNA $(\mathrm{C}=0-75 \mu \mathrm{M}$ for $\mathrm{CuHABH}$ or up to 250 for HESP, HABH; $\mathrm{C}_{\mathrm{CT}}$ DNA $\left.=25 \mu \mathrm{M}\right)$; arrows show the direction of changes. Inset: Stern-Volmer relationship $I_{0} / I$ versus $[D N A]$. (B) Relative fluorescence intensity $\left(I / I_{0}, \%\right)$ at $\lambda_{\mathrm{em}}=527 \mathrm{~nm}$ versus $r$ (=[compound]/[DNA]) in solution of CT DNA-TO adduct.

Author Contributions: Conceptualization, E.Ł.-C.; investigation, A.S., E.G., D.K., A.D., E.K. and L.P.-R.; methodology, E.Ł.-C., E.G., D.K. and E.K.; writing-original draft, A.S., E.Ł.-C., E.G., D.K., A.D. and E.K. All authors have read and agreed to the published version of the manuscript.

Funding: This research received no external funding.

Institutional Review Board Statement: Not applicable.

Informed Consent Statement: Not applicable.

Data Availability Statement: The data presented in this study are available on request from the corresponding author.

Acknowledgments: This research did not receive any specific grant from funding agencies in the public, commercial, or not-for-profit sectors.

Conflicts of Interest: The authors declare that they have no known competing financial interest or personal relationship that could have appeared to influence the work reported in this paper.

Sample Availability: Samples of the compounds (HABH and CuHABH (negligible amount)) are available from the authors.

\section{References}

1. Galiè, S.; García-Gutiérrez, C.; Miguélez, E.M.; Villar, C.J.; Lombó, F. Biofilms in the Food Industry: Health Aspects and Control Methods. Front. Microbiol. 2018, 9, 898. [CrossRef] [PubMed]

2. Abdallah, M.; Benoliel, C.; Drider, D.; Dhulster, P.; Chihib, N.-E. Biofilm formation and persistence on abiotic surfaces in the context of food and medical environments. Arch. Microbiol. 2014, 196, 453-472. [CrossRef] [PubMed]

3. Colagiorgi, A.; Bruini, I.; Di Ciccio, P.A.; Zanardi, E.; Ghidini, S.; Ianieri, A. Listeria monocytogenes Biofilms in the Wonderland of Food Industry. Pathogens 2017, 6, 41. [CrossRef]

4. $\quad$ Cepas, V.; López, Y.; Muñoz, E.; Rolo, D.; Ardanuy, C.; Martí, S.; Xercavins, M.; Horcajada, J.P.; Bosch, J.; Soto, S.M. Relationship Between Biofilm Formation and Antimicrobial Resistance in Gram-Negative Bacteria. Microb. Drug Resist. 2019, 25, 72-79. [CrossRef] [PubMed]

5. Del Pozo, J.L. Biofilm-related disease. Expert Rev. Anti-Infect. Ther. 2017, 16, 51-65. [CrossRef] [PubMed]

6. Hall, C.W.; Mah, T.-F. Molecular mechanisms of biofilm-based antibiotic resistance and tolerance in pathogenic bacteria. FEMS Microbiol. Rev. 2017, 41, 276-301. [CrossRef] [PubMed]

7. Mah, T.-F. Biofilm-specific antibiotic resistance. Futur. Microbiol. 2012, 7, 1061-1072. [CrossRef] [PubMed]

8. Wang, X.; Kong, Y.; Zhao, H.; Yan, X. Dependence of the Bacillus subtilis biofilm expansion rate on phenotypes and the morphology under different growing conditions. Dev. Growth Differ. 2019, 61, 431-443. [CrossRef]

9. Ullah, A.; Munir, S.; Badshah, S.L.; Khan, N.; Ghani, L.; Poulson, B.G.; Emwas, A.-H.; Jaremko, M. Important Flavonoids and Their Role as a Therapeutic Agent. Molecules 2020, 25, 5243. [CrossRef]

10. Roy, R.; Tiwari, M.; Donelli, G.; Tiwari, V. Strategies for combating bacterial biofilms: A focus on anti-biofilm agents and their mechanisms of action. Virulence 2018, 9, 522-554. [CrossRef]

11. Rakesh, K.; Kumara, H.; Ullas, B.; Shivakumara, J.; Gowda, D.C. Amino acids conjugated quinazolinone-Schiff's bases as potential antimicrobial agents: Synthesis, SAR and molecular docking studies. Bioorganic Chem. 2019, 90, 103093. [CrossRef]

12. Oliveira, A.A.; de Oliveira, A.P.A.; Franco, L.L.; Ferencs, M.O.; Ferreira, J.; Bachi, S.M.P.S.; Speziali, N.L.; Farias, L.M.; Magalhães, P.P.; Beraldo, H. 5-Nitroimidazole-derived Schiff bases and their copper(II) complexes exhibit potent antimicrobial activity against pathogenic anaerobic bacteria. BioMetals 2018, 31, 571-584. [CrossRef]

13. More, P.G.; Karale, N.N.; Lawand, A.S.; Narang, N.; Patil, R.H. Synthesis and anti-biofilm activity of thiazole Schiff bases. Med. Chem. Res. 2013, 23, 790-799. [CrossRef]

14. Pervaiz, M.; Ahmad, I.; Yousaf, M.; Kirn, S.; Munawar, A.; Saeed, Z.; Adnan, A.; Gulzar, T.; Kamal, T.; Ahmad, A.; et al. Synthesis, spectral and antimicrobial studies of amino acid derivative Schiff base metal (Co, Mn, Cu, and Cd) complexes. Spectrochim. Acta A Mol. Biomol. Spectrosc. 2018, 206, 642-649. [CrossRef]

15. Mumtaz, A.; Mahmud, T. Structural investigation of some novel synthesized Schiff base Transition metal complexes derived from drug together with Antimicrobial study. Pak. J. Pharm. Sci. 2019, 32, 963-967. [PubMed]

16. Al-Amiery, A.A.; Kadhum, A.A.H.; Mohamad, A.B. Antifungal and Antioxidant Activities of Pyrrolidone Thiosemicarbazone Complexes. Bioinorg. Chem. Appl. 2012, 2012, 1-6. [CrossRef] 
17. Łodyga-Chruścińska, E.; Symonowicz, M.; Sykuła, A.; Bujacz, A.; Garribba, E.; Rowińska-Żyrek, M.; Ołdziej, S.; Klewicka, E.; Janicka, M.; Krolewska, K.; et al. Chelating ability and biological activity of hesperetin Schiff base. J. Inorg. Biochem. 2015, 143, 34-47. [CrossRef]

18. Brodowska, K.; Correia, I.; Garribba, E.; Marques, F.; Klewicka, E.; Lodyga-Chruscinska, E.; Pessoa, J.C.; Dzeikala, A.; Chrusciński, L. Coordination ability and biological activity of a naringenin thiosemicarbazone. J. Inorg. Biochem. 2016, 165, 36-48. [CrossRef]

19. Ramirez, T.; Shrestha, A.; Kishen, A. Inflammatory potential of monospecies biofilm matrix components. Int. Endod. J. 2019, 52, 1020-1027. [CrossRef]

20. Fong, J.N.C.; Yildiz, F.H. Biofilm Matrix Proteins. Microbiol. Spectr. 2015, 3, 1-27. [CrossRef]

21. Gannesen, A.V.; Zdorovenko, E.L.; Botchkova, E.A.; Hardouin, J.; Massier, S.; Kopitsyn, D.S.; Gorbachevskii, M.V.; Kadykova, A.A.; Shashkov, A.S.; Zhurina, M.V.; et al. Composition of the Biofilm Matrix of Cutibacterium acnes Acneic Strain RT5. Front. Microbiol. 2019, 10, 1284. [CrossRef]

22. Li, Y.; Yang, Z.-Y. DNA binding affinity and antioxidative activity of copper(II) and zinc(II) complexes with a novel hesperetin Schiff base ligand. Inorg. Chim. Acta 2009, 362, 4823-4831. [CrossRef]

23. Sykuła, A. Kowalska-Baron, K. Gałęcki, P. Błazińska, E. Łodyga-Chruścińska, Structural and Spectral Investigation of a Series of Flavanone Derivatives. Molecules 2021, 26, 1298. [CrossRef]

24. Gans, P.; Sabatini, A.; Vacca, A. SUPERQUAD: An improved general program for computation of formation constants from potentiometric data. J. Chem. Soc. Dalton Trans. 1985, 1195-1200. [CrossRef]

25. WinEPR SimFonia, Version 1.25. Bruker Analytische Messtechnik GmbH: Karlshrue. 1996. Available online: https:// www.bruker. com/en/products-and-solutions/mr/epr-instruments/epr-software/winepr.html (accessed on 26 December 2021).

26. Frisch, M.J.; Trucks, G.W.; Schlegel, H.B.; Scuseria, G.E.; Robb, M.A.; Cheeseman, J.R.; Scalmani, G.; Barone, V.; Mennucci, B.; Petersson, G.A.; et al. Fox Gaussian 09; revision D.01; Gaussian, Inc.: Wallingford, CT, USA, 2010. Available online: https: / /gaussian.com (accessed on 26 December 2021).

27. Becke, A.D. Density-functional thermochemistry. III. The role of exact exchange. J. Chem. Phys. 1993, 98, 5648-5652. [CrossRef]

28. Lee, C.; Yang, W.; Parr, R.G. Development of the Colle-Salvetti correlation-energy formula into a functional of the electron density. Phys. Rev. B 1988, 37, 785-789. [CrossRef]

29. Bühl, M.; Kabrede, H. Geometries of Transition-Metal Complexes from Density-Functional Theory. J. Chem. Theory Comput. 2006, 2, 1282-1290. [CrossRef]

30. Buehl, M.; Reimann, C.; Pantazis, D.A.; Bredow, T.; Neese, F. Geometries of Third-Row Transition-Metal Complexes from Density-Functional Theory. J. Chem. Theory Comput. 2008, 4, 1449-1459. [CrossRef] [PubMed]

31. Micera, G.; Garribba, E. The effect of the functional, basis set, and solvent in the simulation of the geometry and spectroscopic properties of V. Int. J. Quantum Chem. 2012, 112, 2486-2498. [CrossRef]

32. Neese, F. ORCA - An Ab Initio, DFT and Semiempirical Program Package, Version 4.0, Max-Planck-Institute for Chemical Energy Conversion, Mülheim a. d. Ruhr. 2017. Available online: https://orcaforum.kofo.mpg.de/app.php/portal (accessed on 26 December 2021).

33. Neese, F. Software update: The ORCA program system, version 4.0. Wiley Interdiscip. Rev. Comput. Mol. Sci. 2018, 8, e1327. [CrossRef]

34. Neese, F.; Wennmohs, F.; Becker, U.; Riplinger, C. The ORCA quantum chemistry program package. J. Chem. Phys. 2020, 152, 224108. [CrossRef]

35. Perdew, J.P.; Burke, K.; Ernzerhof, M. Generalized gradient approximation made simple. Phys. Rev. Lett. 1996, 77, 3865-3868. [CrossRef]

36. Perdew, J.P.; Burke, K.; Ernzerhof, M. Generalized Gradient Approximation Made Simple [Phys. Rev. Lett. 77, 3865 (1996)]. Phys. Rev. Lett. 1997, 78, 1396. [CrossRef]

37. Sciortino, G.; Lubinu, G.; Maréchal, J.-D.; Garribba, E. DFT Protocol for EPR Prediction of Paramagnetic Cu(II) Complexes and Application to Protein Binding Sites. Magnetochemistry 2018, 4, 55. [CrossRef]

38. Wolfe, G.H.; Shimer, T. Mechan, Polycyclic aromatic hydrocarbons physically intercalate into duplex regions of denatured DNA. Biochemistry 1987, 26, 6392-6396. [CrossRef]

39. Boger, D.L.; Tse, W.C. Thiazole orange as the fluorescent intercalator in a high resolution fid assay for determining DNA binding affinity and sequence selectivity of small molecules. Bioorg. Med. Chem. 2001, 9, 2511-2518. [CrossRef]

40. Lakowicz, J.R. Principles of Fluorescence Spectroscopy, 3rd ed.; Springer: New York, NY, USA, 2006; p. 11

41. Eftink, M.R. Fluorescence Quenching: Theory and Applications. In Topics in Fluorescence Spectroscopy; Lakowicz, J.R., Ed.; Springer: Boston, MA, USA, 2002; Volume 2, pp. 53-126. [CrossRef]

42. Algar, W.R.; Massey, M.; Krull, U.J. Fluorescence Resonance Energy Transfer and Complex Formation between Thiazole Orange and Various Dye-DNA Conjugates: Implications in Signaling Nucleic Acid Hybridization. J. Fluoresc. 2006, 16, 555-567. [CrossRef]

43. EUCAST. EUCAST Disk Diffusion Test Methodology. Available online: https://www.eucast.org/ast_of_bacteria/disk_diffusion_ methodology / (accessed on 26 November 2021).

44. Piccirillo, C.; Demiray, S.; Ferreira, A.S.; Pintado, M.; Castro, P. Chemical composition and antibacterial properties of stem and leaf extracts from Ginja cherry plant. Ind. Crop. Prod. 2012, 43, 562-569. [CrossRef]

45. Kregiel, D.; Rygala, A.; Kolesinska, B.; Nowacka, M.; Herc, A.S.; Kowalewska, A. Antimicrobial and Antibiofilm N-acetyl-Lcysteine Grafted Siloxane Polymers with Potential for Use in Water Systems. Int. J. Mol. Sci. 2019, 20, 2011. [CrossRef] 
46. Myszka, K.; Czaczyk, K. Effect of starvation stress on morphological changes and production of adhesive exopolysaccharide (EPS) by Proteus vulgaris. Acta Sci. Pol. Technol. Aliment. 2011, 10, 305-312.

47. Nagesh, G.Y.; Mahadev, U.D.; Mruthyunjayaswamy, B.H.M. Mononuclear Metal (II) Schiff Base complexes derived from thiazole and o-vanillin moieties: Synthesis, characterization, Thermal Behaviour and Biological Evaluation. Int. J. Pharm. Sci. Rev. Res. 2015, 31, 190-197. Available online: https://globalresearchonline.net/journalcontents/v31-1/38.pdf (accessed on 22 November 2021).

48. Chandra, S.; Gupta, L.K. Electronic, EPR, magnetic and mass spectral studies of mono and homo-binuclear Co(II) and Cu(II) complexes with a novel macrocyclic ligand. Spectrochim. Acta Part. A Mol. Biomol. Spectrosc. 2005, 62, 1102-1106. [CrossRef] [PubMed]

49. Peisach, J.; Blumberg, W. Structural implications derived from the analysis of electron paramagnetic resonance spectra of natural and artificial copper proteins. Arch. Biochem. Biophys. 1974, 165, 691-708. [CrossRef]

50. Garribba, E.; Micera, G. The Determination of the Geometry of Cu(II) Complexes: An EPR Spectroscopy Experiment. J. Chem. Educ. 2006, 83, 1229-1232. [CrossRef]

51. Xu, Y.; Chen, D. Studies of EPR and ENDOR spectra of14N and15N label bis(2-hydroxyacetophenyl ketoxime)-63Cu(II) and65Cu(II) complexes in disordered system. Appl. Magn. Reson. 1996, 10, 103-116. [CrossRef]

52. Cunningham, K.L.; McNett, K.M.; Pierce, R.A.; Davis, K.A.; Harris, H.H.; Falck, A.D.M.; McMillin, D.R. EPR Spectra, Luminescence Data, and Radiationless Decay Processes of Copper(II) Porphyrins. Inorg. Chem. 1997, 36, 608-613. [CrossRef]

53. Klement, R.; Stock, F.; Elias, H.; Paulus, H.; Pelikán, P.; Valko, M.; Mazúr, M. Copper(II) complexes with derivatives of salen and tetrahydrosalen: A spectroscopic, electrochemical and structural study. Polyhedron 1999, 18, 3617-3628. [CrossRef]

54. Thakurta, S.; Chakraborty, J.; Rosair, G.; Tercero, J.; El Fallah, M.S.; Garribba, E.; Mitra, S. Synthesis of Two New Linear Trinuclear CuIIComplexes: Mechanism of Magnetic Coupling through Hybrid B3LYP Functional and CShM Studies. Inorg. Chem. 2008, 47, 6227-6235. [CrossRef]

55. Neese, F. Metal and ligand hyperfine couplings in transition metal complexes: The effect of spin-orbit coupling as studied by coupled perturbed Kohn-Sham theory. J. Chem. Phys. 2003, 118, 3939-3948. [CrossRef]

56. Sanna, D.; Ágoston, C.G.; Micera, G.; Sóvágó, I. The effect of the ring size of fused chelates on the thermodynamic and spectroscopic properties of peptide complexes of copper(II). Polyhedron 2001, 20, 3079-3090. [CrossRef]

57. Zeglis, B.M.; Pierre, V.C.; Barton, J.K. Metallo-intercalators and metallo-insertors. Chem. Commun. 2007, 44, 4565-4579. [CrossRef]

58. Pyle, A.M.; Rehmann, J.P.; Meshoyrer, R.; Kumar, C.V.; Turro, N.J.; Barton, J.K. Mixed-ligand complexes of ruthenium(II): Factors governing binding to DNA. J. Am. Chem. Soc. 1989, 111, 3051-3058. [CrossRef]

59. Gupta, R.K.; Pandey, R.; Sharma, G.; Prasad, R.; Koch, B.; Srikrishna, S.; Li, P.-Z.; Xu, Q.; Pandey, D.S. DNA Binding and Anti-Cancer Activity of Redox-Active Heteroleptic Piano-Stool Ru(II), Rh(III), and Ir(III) Complexes Containing 4-(2Methoxypyridyl)phenyldipyrromethene. Inorg. Chem. 2013, 52, 3687-3698. [CrossRef]

60. Mancin, F.; Scrimin, P.; Tecilla, P.; Tonellato, U. Artificial metallonucleases. Chem. Commun. 2005, 36, 2540-2548. [CrossRef]

61. Lang, K.; Kubát, P.; Lhoták, P.; Mosinger, J.; Wagnerová, D.M. Photophysical Properties and Photoinduced Electron Transfer within Host-Guest Complexes of 5,10,15,20-Tetrakis(4-N-methylpyridyl)porphyrin with Water-soluble Calixarenes and Cyclodextrins. Photochem. Photobiol. 2007, 74, 558-565. [CrossRef]

62. Chikira, M.; Tomizawa, Y.; Fukita, D.; Sugizaki, T.; Sugawara, N.; Yamazaki, T.; Sasano, A.; Shindo, H.; Palaniandavar, M.; Antholine, W.E. DNA-fiber EPR study of the orientation of Cu(II) complexes of 1,10-phenanthroline and its derivatives bound to DNA: Mono(phenanthroline)-copper(II) and its ternary complexes with amino acids. J. Inorg. Biochem. 2002, 89, 163-173. [CrossRef]

63. Silva, G.L.; Ediz, V.; Yaron, D.; Armitage, B.A. Experimental and Computational Investigation of Unsymmetrical Cyanine Dyes: Understanding Torsionally Responsive Fluorogenic Dyes. J. Am. Chem. Soc. 2007, 129, 5710-5718. [CrossRef]

64. Bunkenborg, J.; Gadjev, N.I.; Deligeorgiev, T.; Jacobsen, J.P. Concerted Intercalation and Minor Groove Recognition of DNA by a Homodimeric Thiazole Orange Dye. Bioconjugate Chem. 2000, 11, 861-867. [CrossRef]

65. Nygren, J.; Svanvik, N.; Kubista, M. The interactions between the fluorescent dye thiazole orange and DNA. Biopolymers 1998, 46, 39-51. [CrossRef]

66. Privat, E.; Melvin, T.; Mérola, F.; Schweizer, G.; Prodhomme, S.; Asseline, U.; Vigny, P. Fluorescent properties of oligonucleo-tideconjugated thiazole orange probes. Photochem. Photobiol. 2002, 75, 201-210. [CrossRef]

67. Muskalska, B.; Szymczak, B. Progress in research on the genus Listeria. Post. Mikrobiol. 2015, 54, 123-132.

68. Brown, M.R.W.; Williams, P. The influence of environment on envelope properties affecting survival of bacteria in infections. Ann. Rev. Microbiol. 1985, 39, 527-556. [CrossRef] [PubMed]

69. Manning, A.J.; Kuehn, M.J. Functional Advantages Conferred by Extracellular Prokaryotic Membrane Vesicles. J. Mol. Microbiol. Biotechnol. 2013, 23, 131-141. [CrossRef] [PubMed]

70. Schaar, V.; Nordström, T.; Mörgelin, M.; Riesbeck, K. Moraxella catarrhalisOuter Membrane Vesicles Carry $\beta$-Lactamase and Promote Survival ofStreptococcus pneumoniaeandHaemophilus influenzaeby Inactivating Amoxicillin. Antimicrob. Agents Chemother. 2011, 55, 3845-3853. [CrossRef]

71. Wasążnik, A.; Grinholc, M.; Bielawski, K.P. Active efflux as the multidrug resistance mechanism. Postepy Hig Med Dosw. 2009, 63, 123-133.

72. Tintino, S.R.; Morais-Tintino, C.D.; Campina, F.F.; Costa, M.S.; Menezes, I.R.A.; de Matos, Y.M.L.S.; Calixto-Júnior, J.T.; Pereira, P.S.; Siqueira-Junior, J.P.; Leal-Balbino, T.C.; et al. Tannic acid affects the phenotype of Staphylococcus aureus resistant totetracycline and erythromycin by inhibition of efflux pumps. Bioorganic Chemistry. 2017, 74, 197-200. [CrossRef] 
73. Dos Santos, J.F.; Tintino, S.R.; de Freitas, T.S.; Campina, F.F.; Menezes, I.R.D.A.; Siqueira-Júnior, J.P.; Coutinho, H.D.; Cunha, F.A. In vitro e in silico evaluation of the inhibition of Staphylococcus aureus efflux pumps by caffeic and gallic acid. Comp. Immunol. Microbiol. Infect. Dis. 2018, 57, 22-28. [CrossRef]

74. Figueredo, F.G.; Ramos, I.T.D.L.; Paz, J.A.; Silva, T.M.; Câmara, C.A.; Oliveira-Tintino, C.D.D.M.; Tintino, S.R.; Farias, P.; de Menezes, I.R.A.; Coutinho, H.D.M.; et al. Effect of hydroxyamines derived from lapachol and norlachol against Staphylococcus aureus strains carrying the NorA efflux pump. Infect. Genet. Evol. 2020, 84, 104370. [CrossRef]

75. Menezes, I.R.A.; Coutinho, H.D.M.; Pinheiro, P.G.; Santiago, G.M.P.; da Silva, F.E.F.; de Araújo, A.C.J.; de Oliveira, C.R.T.; Freitas, P.R.; Rocha, J.E.; Neto, J.B.D.A.; et al. Antibacterial activity and inhibition against Staphylococcus aureus NorA efflux pump by ferulic acid and its esterified derivatives. Asian Pac. J. Trop. Biomed. 2021, 11, 405. [CrossRef]

76. Dos Santos, J.F.S.; Tintino, S.R.; da Silva, A.R.P.; Barbosa, C.R.d.S.; Scherf, J.R.; Silveira, Z.d.S.; de Freitas, T.S.; Neto, L.J.d.L.; Barros, L.M.; Menezes, I.R.d.A.; et al. Enhancement of the antibiotic activity by quercetin against Staphylococcus aureus efflux pumps. J. Bioenerg. Biomembr. 2021, 53, 157-167. [CrossRef]

77. Absolom, D.R.; Lamberti, F.V.; Policova, Z.; Zingg, W.; van Oss, C.J.; Neumann, A.W. Surface thermodynamics of bacterial adhesion. Appl. Environ. Microbiol. 1983, 46, 90-97. [CrossRef]

78. Ruan, B.; Wu, P.; Liu, J.; Jiang, L.; Wang, H.; Qiao, J.; Zhu, N.; Dang, Z.; Luo, H.; Yi, X. Adhesion of Sphingomonas sp. GY2B onto montmorillonite: A combination study by thermodynamics and the extended DLVO theory. Colloids Surf. B Biointerfaces 2020, 192, 111085. [CrossRef]

79. O'Gara, J.P. icaand beyond: Biofilm mechanisms and regulation in Staphylococcus epidermidis and Staphylococcus aureus. FEMS Microbiol. Lett. 2007, 270, 179-188. [CrossRef]

80. Duvernoy, M.-C.; Mora, T.; Ardré, M.; Croquette, V.; Bensimon, D.; Quilliet, C.; Ghigo, J.-M.; Balland, M.; Beloin, C.; Lecuyer, S.; et al. Asymmetric adhesion of rod-shaped bacteria controls microcolony morphogenesis. Nat. Commun. 2018, 9,1-10. [CrossRef]

81. Kregiel, D. Adhesion of Aeromonas hydrophila to glass surfaces modified with organosilanes. Food Technol. Biotechnol. 2013, 51, 345-351.

82. Nowacka, M.; Rygała, A.; Kręgiel, D.; Kowalewska, A. New Antiadhesive Hydrophobic Polysiloxanes. Molecules 2021, 26, 814. [CrossRef]

83. Sánchez-López, E.; Gomes, D.; Esteruelas, G.; Bonilla, L.; Lopez-Machado, A.L.; Galindo, R.; Cano, A.; Espina, M.; Ettcheto, M.; Camins, A.; et al. Metal-Based Nanoparticles as Antimicrobial Agents: An Overview. Nanomaterials 2020, 10, 292. [CrossRef]

84. Abbaszadegan, A.; Ghahramani, Y.; Gholami, A.; Hemmateenejad, B.; Dorostkar, S.; Nabavizadeh, M.; Sharghi, H. The Effect of Charge at the Surface of Silver Nanoparticles on Antimicrobial Activity against Gram-Positive and Gram-Negative Bacteria: A Preliminary Study. J. Nanomater. 2015, 2015, 1-8. [CrossRef]

85. Correa, M.G.; Martínez, F.B.; Vidal, C.P.; Streitt, C.; Escrig, J.; De Dicastillo, C.L. Antimicrobial metal-based nanoparticles: A review on their synthesis, types and antimicrobial action. Beilstein J. Nanotechnol. 2020, 11, 1450-1469. [CrossRef]

86. Simon, A.T.; Dutta, D.; Chattopadhyay, A.; Ghosh, S.S. Copper Nanocluster-Doped Luminescent Hydroxyapatite Nanoparticles for Antibacterial and Antibiofilm Applications. ACS Omega 2019, 4, 4697-4706. [CrossRef]

87. Subramaniyan, S.B.; Vijayakumar, S.; Megarajan, S.; Kamlekar, R.K.; Anbazhagan, V. Remarkable Effect of Jacalin in Diminishing the Protein Corona Interference in the Antibacterial Activity of Pectin-Capped Copper Sulfide Nanoparticles. ACS Omega 2019, 4, 14049-14056. [CrossRef] [PubMed]

88. Haeili, M.; Moore, C.; Davis, C.J.C.; Cochran, J.B.; Shah, S.; Shrestha, T.B.; Zhang, Y.; Bossmann, S.H.; Benjamin, W.H.; Kutsch, O.; et al. Copper Complexation Screen Reveals Compounds with Potent Antibiotic Properties against Methicillin-Resistant Staphylococcus aureus. Antimicrob. Agents Chemother. 2014, 58, 3727-3736. [CrossRef] [PubMed]

89. Brahma, U.; Kothari, R.; Sharma, P.; Bhandari, V. Antimicrobial and anti-biofilm activity of hexadentated macrocyclic complex of copper (II) derived from thiosemicarbazide against Staphylococcus aureus. Sci. Rep. 2018, 8, 1-8. [CrossRef] [PubMed]

90. Duarte, S.; Gregoire, S.; Singh, A.P.; Vorsa, N.; Schaich, K.; Bowen, W.H.; Koo, H. Inhibitory effects of cranberry polyphenols on formation and acidogenicity ofStreptococcus mutansbiofilms. FEMS Microbiol. Lett. 2006, 257, 50-56. [CrossRef]

91. Abuelsaad, A.S.; Allam, G.; Al-Solumani, A.A. Hesperidin inhibits inflammatory response induced by Aeromonas hydrophila infec-tion and alters CD4+/CD8+ T cell ratio. Med. Inflamm. 2014, 2014, 393217. [CrossRef]

92. Alalwan, H.K.A.; Rajendran, R.; Lappin, D.F.; Combet, E.; Shahzad, M.; Robertson, D.; Nile, C.; Williams, C.; Ramage, G. The Anti-Adhesive Effect of Curcumin on Candida albicans Biofilms on Denture Materials. Front. Microbiol. 2017, 8, 659. [CrossRef]

93. Lee, J.-H.; Park, J.-H.; Cho, M.H.; Lee, J. Flavone Reduces the Production of Virulence Factors, Staphyloxanthin and $\alpha$-Hemolysin, in Staphylococcus aureus. Curr. Microbiol. 2012, 65, 726-732. [CrossRef]

94. Lee, J.-H.; Regmi, S.C.; Kim, J.-A.; Cho, M.H.; Yun, H.; Lee, C.-S.; Lee, J. Apple Flavonoid Phloretin Inhibits Escherichia coli O157:H7 Biofilm Formation and Ameliorates Colon Inflammation in Rats. Infect. Immun. 2011, 79, 4819-4827. [CrossRef]

95. Kaur, A.; Sharma, P.; Capalash, N. Curcumin alleviates persistence of Acinetobacter baumannii against colistin. Sci. Rep. 2018, 8, 1-11. [CrossRef]

96. Muthusamy, B.; Shanmugam, G. Analysis of flavonoid content, antioxidant, antimicrobial and antibiofilm activity of in vitro hairy root extract of radish (Raphanus satious L.). Plant Cell Tissue Organ. Cult. (PCTOC) 2020, 140, 619-633. [CrossRef]

97. Lopes, L.A.A.; Rodrigues, J.B.D.S.; Magnani, M.; de Souza, E.L.; de Siqueira-Júnior, J.P. Inhibitory effects of flavonoids on biofilm formation by Staphylococcus aureus that overexpresses efflux protein genes. Microb. Pathog. 2017, 107, 193-197. [CrossRef] 